\title{
Biogenic processes in crystalline bedrock fractures indicated by carbon isotope signatures of secondary calcite
}

\section{Sahlstedt, Elina}

\section{6}

Sahlstedt , E , Karhu , J A , Pitkänen , P \& Whitehouse , M 2016 , ' Biogenic processes in crystalline bedrock fractures indicated by carbon isotope signatures of secondary calcite ' Applied Geochemistry , vol. 67 , pp. 30-41 . https://doi.org/10.1016/j.apgeochem.2016.01.010

http://hdl.handle.net/10138/186576

https://doi.org/10.1016/j.apgeochem.2016.01.010

acceptedVersion

Downloaded from Helda, University of Helsinki institutional repository.

This is an electronic reprint of the original article.

This reprint may differ from the original in pagination and typographic detail.

Please cite the original version. 
2

5

\section{Abstract \\ Abstract}

4 a Department of Geosciences and Geography, University of Helsinki, P.O. Box 64, 00014 Helsinki,

Variation in ${ }^{13} \mathrm{C} /{ }^{12} \mathrm{C}$-isotope ratios of fracture filling calcite was analyzed in situ to investigate
carbon sources and cycling in fractured bedrock. The study was conducted by separating sections of

Variation in ${ }^{13} \mathrm{C} /{ }^{12} \mathrm{C}$-isotope ratios of fracture filling calcite was analyzed in situ to investigate
carbon sources and cycling in fractured bedrock. The study was conducted by separating sections of fracture fillings, and analyzing the ${ }^{13} \mathrm{C} /{ }^{12} \mathrm{C}$-ratios with secondary ion mass spectrometry (SIMS). Specifically, the study was aimed at fillings where previously published sulfur isotope data
indicated the occurrence of bacterial sulfate reduction. The results showed that the $\delta^{13} \mathrm{C}$ values of Specifically, the study was aimed at fillings where previously published sulfur isotope data
indicated the occurrence of bacterial sulfate reduction. The results showed that the $\delta^{13} \mathrm{C}$ values of calcite were highly variable, ranging from $-53.8 \%$ o to $+31.8 \%$ (VPDB). The analysis also showed
1 Biogenic processes in crystalline bedrock fractures indicated by carbon isotope signatures of

secondary calcite

Elina Sahlstedt ${ }^{\mathrm{a}}$, Juha A. Karhu ${ }^{\mathrm{a}}$, Petteri Pitkänen ${ }^{\mathrm{b}}$, Martin Whitehouse $^{\mathrm{c}}$ Finland, Emails: elina.sahlstedt@helsinki.fi or juha.karhu@helsinki.fi

Corresponding author: Elina Sahlstedt, phone: $+358-504480225$, fax: $+358-9-191-50826$

(1)

\footnotetext{
high variations within single fillings of up to $39 \%$. The analyzed calcite fillings were mostly
associated with two calcite groups, of which Group 3 represents possible Paleozoic fluid
circulation, based on comparison with similar dated coatings within the Baltic Shield and the
succeeding Group $1-2$ fillings represent late-stage, low temperature mineralization and are possibly
late Paleozoic to Quaternary in age. Both generations were associated with pyrite with $\delta^{34} \mathrm{~S}$ values
indicative of bacterial sulfate reduction. The $\delta^{13} \mathrm{C}$ values of calcite, however, were indicative of
geochemical environments which were distinct for these generations. The $\delta^{13} \mathrm{C}$ values of Group 3
calcite varied from -22.1\%o to $+11 \%$, with a distinct peak at - $16 \%$ to $-12 \%$. Furthermore, there
were no observable depth dependent trends in the $\delta^{13} \mathrm{C}$ values of Group 3 calcite. The $\delta^{13} \mathrm{C}$ values of
Group 3 calcite were indicative of organic matter degradation and methanogenesis. In contrast to
the Group 3 fillings, the $\delta^{13} \mathrm{C}$ values of Group $1-2$ calcite were highly variable, ranging from -
$53.8 \%$ to $+31.8 \%$ and they showed systematic variation with depth. The near surface environment high variations within single fillings of up to $39 \%$. The analyzed calcite fillings were mostly
associated with two calcite groups, of which Group 3 represents possible Paleozoic fluid
circulation, based on comparison with similar dated coatings within the Baltic Shield and the
succeeding Group 1-2 fillings represent late-stage, low temperature mineralization and are possibly
late Paleozoic to Quaternary in age. Both generations were associated with pyrite with $\delta^{34} \mathrm{~S}$ values
indicative of bacterial sulfate reduction. The $\delta^{13} \mathrm{C}$ values of calcite, however, were indicative of
geochemical environments which were distinct for these generations. The $\delta^{13} \mathrm{C}$ values of Group 3
calcite varied from $-22.1 \%$ to $+11 \%$, with a distinct peak at $-16 \%$ to $-12 \%$. Furthermore, there
were no observable depth dependent trends in the $\delta^{13} \mathrm{C}$ values of Group 3 calcite. The $\delta^{13} \mathrm{C}$ values of
Group 3 calcite were indicative of organic matter degradation and methanogenesis. In contrast to
the Group 3 fillings, the $\delta^{13} \mathrm{C}$ values of Group $1-2$ calcite were highly variable, ranging from -
$53.8 \%$ to $+31.8 \%$ and they showed systematic variation with depth. The near surface environment high variations within single fillings of up to $39 \%$. The analyzed calcite fillings were mostly
associated with two calcite groups, of which Group 3 represents possible Paleozoic fluid
circulation, based on comparison with similar dated coatings within the Baltic Shield and the
succeeding Group 1-2 fillings represent late-stage, low temperature mineralization and are possibly
late Paleozoic to Quaternary in age. Both generations were associated with pyrite with $\delta^{34} \mathrm{~S}$ values
indicative of bacterial sulfate reduction. The $\delta^{13} \mathrm{C}$ values of calcite, however, were indicative of
geochemical environments which were distinct for these generations. The $\delta^{13} \mathrm{C}$ values of Group 3
calcite varied from $-22.1 \%$ to $+11 \%$, with a distinct peak at $-16 \%$ to $-12 \%$. Furthermore, there
were no observable depth dependent trends in the $\delta^{13} \mathrm{C}$ values of Group 3 calcite. The $\delta^{13} \mathrm{C}$ values of
Group 3 calcite were indicative of organic matter degradation and methanogenesis. In contrast to
the Group 3 fillings, the $\delta^{13} \mathrm{C}$ values of Group $1-2$ calcite were highly variable, ranging from -
$53.8 \%$ to $+31.8 \%$ and they showed systematic variation with depth. The near surface environment high variations within single fillings of up to $39 \%$. The analyzed calcite fillings were mostly
associated with two calcite groups, of which Group 3 represents possible Paleozoic fluid
circulation, based on comparison with similar dated coatings within the Baltic Shield and the
succeeding Group 1-2 fillings represent late-stage, low temperature mineralization and are possibly
late Paleozoic to Quaternary in age. Both generations were associated with pyrite with $\delta^{34} \mathrm{~S}$ values
indicative of bacterial sulfate reduction. The $\delta^{13} \mathrm{C}$ values of calcite, however, were indicative of
geochemical environments which were distinct for these generations. The $\delta^{13} \mathrm{C}$ values of Group 3
calcite varied from $-22.1 \%$ to $+11 \%$, with a distinct peak at $-16 \%$ to $-12 \%$. Furthermore, there
were no observable depth dependent trends in the $\delta^{13} \mathrm{C}$ values of Group 3 calcite. The $\delta^{13} \mathrm{C}$ values of
Group 3 calcite were indicative of organic matter degradation and methanogenesis. In contrast to
the Group 3 fillings, the $\delta^{13} \mathrm{C}$ values of Group $1-2$ calcite were highly variable, ranging from -
$53.8 \%$ to $+31.8 \%$ and they showed systematic variation with depth. The near surface environment high variations within single fillings of up to $39 \%$. The analyzed calcite fillings were mostly
associated with two calcite groups, of which Group 3 represents possible Paleozoic fluid
circulation, based on comparison with similar dated coatings within the Baltic Shield and the
succeeding Group 1-2 fillings represent late-stage, low temperature mineralization and are possibly
late Paleozoic to Quaternary in age. Both generations were associated with pyrite with $\delta^{34} \mathrm{~S}$ values
indicative of bacterial sulfate reduction. The $\delta^{13} \mathrm{C}$ values of calcite, however, were indicative of
geochemical environments which were distinct for these generations. The $\delta^{13} \mathrm{C}$ values of Group 3
calcite varied from $-22.1 \%$ to $+11 \%$, with a distinct peak at $-16 \%$ to $-12 \%$. Furthermore, there
were no observable depth dependent trends in the $\delta^{13} \mathrm{C}$ values of Group 3 calcite. The $\delta^{13} \mathrm{C}$ values of
Group 3 calcite were indicative of organic matter degradation and methanogenesis. In contrast to
the Group 3 fillings, the $\delta^{13} \mathrm{C}$ values of Group $1-2$ calcite were highly variable, ranging from -
$53.8 \%$ to $+31.8 \% o$ and they showed systematic variation with depth. The near surface environment high variations within single fillings of up to $39 \%$. The analyzed calcite fillings were mostly
associated with two calcite groups, of which Group 3 represents possible Paleozoic fluid
circulation, based on comparison with similar dated coatings within the Baltic Shield and the
succeeding Group 1-2 fillings represent late-stage, low temperature mineralization and are possibly
late Paleozoic to Quaternary in age. Both generations were associated with pyrite with $\delta^{34} \mathrm{~S}$ values
indicative of bacterial sulfate reduction. The $\delta^{13} \mathrm{C}$ values of calcite, however, were indicative of
geochemical environments which were distinct for these generations. The $\delta^{13} \mathrm{C}$ values of Group 3
calcite varied from $-22.1 \%$ to $+11 \%$, with a distinct peak at $-16 \%$ to $-12 \%$. Furthermore, there
were no observable depth dependent trends in the $\delta^{13} \mathrm{C}$ values of Group 3 calcite. The $\delta^{13} \mathrm{C}$ values of
Group 3 calcite were indicative of organic matter degradation and methanogenesis. In contrast to
the Group 3 fillings, the $\delta^{13} \mathrm{C}$ values of Group $1-2$ calcite were highly variable, ranging from -
$53.8 \%$ to $+31.8 \% o$ and they showed systematic variation with depth. The near surface environment high variations within single fillings of up to $39 \%$. The analyzed calcite fillings were mostly
associated with two calcite groups, of which Group 3 represents possible Paleozoic fluid
circulation, based on comparison with similar dated coatings within the Baltic Shield and the
succeeding Group 1-2 fillings represent late-stage, low temperature mineralization and are possibly
late Paleozoic to Quaternary in age. Both generations were associated with pyrite with $\delta^{34} \mathrm{~S}$ values
indicative of bacterial sulfate reduction. The $\delta^{13} \mathrm{C}$ values of calcite, however, were indicative of
geochemical environments which were distinct for these generations. The $\delta^{13} \mathrm{C}$ values of Group 3
calcite varied from $-22.1 \%$ to $+11 \%$, with a distinct peak at $-16 \%$ to $-12 \%$. Furthermore, there
were no observable depth dependent trends in the $\delta^{13} \mathrm{C}$ values of Group 3 calcite. The $\delta^{13} \mathrm{C}$ values of
Group 3 calcite were indicative of organic matter degradation and methanogenesis. In contrast to
the Group 3 fillings, the $\delta^{13} \mathrm{C}$ values of Group $1-2$ calcite were highly variable, ranging from -
$53.8 \%$ to $+31.8 \%$ and they showed systematic variation with depth. The near surface environment high variations within single fillings of up to $39 \%$. The analyzed calcite fillings were mostly
associated with two calcite groups, of which Group 3 represents possible Paleozoic fluid
circulation, based on comparison with similar dated coatings within the Baltic Shield and the
succeeding Group 1-2 fillings represent late-stage, low temperature mineralization and are possibly
late Paleozoic to Quaternary in age. Both generations were associated with pyrite with $\delta^{34} \mathrm{~S}$ values
indicative of bacterial sulfate reduction. The $\delta^{13} \mathrm{C}$ values of calcite, however, were indicative of
geochemical environments which were distinct for these generations. The $\delta^{13} \mathrm{C}$ values of Group 3
calcite varied from -22.1\%o to $+11 \%$, with a distinct peak at $-16 \%$ to $-12 \%$. Furthermore, there
were no observable depth dependent trends in the $\delta^{13} \mathrm{C}$ values of Group 3 calcite. The $\delta^{13} \mathrm{C}$ values of
Group 3 calcite were indicative of organic matter degradation and methanogenesis. In contrast to
the Group 3 fillings, the $\delta^{13} \mathrm{C}$ values of Group $1-2$ calcite were highly variable, ranging from -
$53.8 \%$ to $+31.8 \%$ and they showed systematic variation with depth. The near surface environment high variations within single fillings of up to $39 \%$. The analyzed calcite fillings were mostly
associated with two calcite groups, of which Group 3 represents possible Paleozoic fluid
circulation, based on comparison with similar dated coatings within the Baltic Shield and the
succeeding Group 1-2 fillings represent late-stage, low temperature mineralization and are possibly
late Paleozoic to Quaternary in age. Both generations were associated with pyrite with $\delta^{34} \mathrm{~S}$ values
indicative of bacterial sulfate reduction. The $\delta^{13} \mathrm{C}$ values of calcite, however, were indicative of
geochemical environments which were distinct for these generations. The $\delta^{13} \mathrm{C}$ values of Group 3
calcite varied from $-22.1 \%$ to $+11 \%$, with a distinct peak at $-16 \%$ to $-12 \%$. Furthermore, there
were no observable depth dependent trends in the $\delta^{13} \mathrm{C}$ values of Group 3 calcite. The $\delta^{13} \mathrm{C}$ values of
Group 3 calcite were indicative of organic matter degradation and methanogenesis. In contrast to
the Group 3 fillings, the $\delta^{13} \mathrm{C}$ values of Group $1-2$ calcite were highly variable, ranging from -
$53.8 \%$ to $+31.8 \%$ and they showed systematic variation with depth. The near surface environment high variations within single fillings of up to $39 \%$. The analyzed calcite fillings were mostly
associated with two calcite groups, of which Group 3 represents possible Paleozoic fluid
circulation, based on comparison with similar dated coatings within the Baltic Shield and the
succeeding Group $1-2$ fillings represent late-stage, low temperature mineralization and are possibly
late Paleozoic to Quaternary in age. Both generations were associated with pyrite with $\delta^{34} \mathrm{~S}$ values
indicative of bacterial sulfate reduction. The $\delta^{13} \mathrm{C}$ values of calcite, however, were indicative of
geochemical environments which were distinct for these generations. The $\delta^{13} \mathrm{C}$ values of Group 3
calcite varied from -22.1\%o to $+11 \%$, with a distinct peak at - $16 \%$ to $-12 \%$. Furthermore, there
were no observable depth dependent trends in the $\delta^{13} \mathrm{C}$ values of Group 3 calcite. The $\delta^{13} \mathrm{C}$ values of
Group 3 calcite were indicative of organic matter degradation and methanogenesis. In contrast to
the Group 3 fillings, the $\delta^{13} \mathrm{C}$ values of Group $1-2$ calcite were highly variable, ranging from -
$53.8 \%$ to $+31.8 \%$ and they showed systematic variation with depth. The near surface environment high variations within single fillings of up to $39 \%$. The analyzed calcite fillings were mostly
associated with two calcite groups, of which Group 3 represents possible Paleozoic fluid
circulation, based on comparison with similar dated coatings within the Baltic Shield and the
succeeding Group 1-2 fillings represent late-stage, low temperature mineralization and are possibly
late Paleozoic to Quaternary in age. Both generations were associated with pyrite with $\delta^{34} \mathrm{~S}$ values
indicative of bacterial sulfate reduction. The $\delta^{13} \mathrm{C}$ values of calcite, however, were indicative of
geochemical environments which were distinct for these generations. The $\delta^{13} \mathrm{C}$ values of Group 3
calcite varied from -22.1\%o to $+11 \%$, with a distinct peak at $-16 \%$ to $-12 \%$. Furthermore, there
were no observable depth dependent trends in the $\delta^{13} \mathrm{C}$ values of Group 3 calcite. The $\delta^{13} \mathrm{C}$ values of
Group 3 calcite were indicative of organic matter degradation and methanogenesis. In contrast to
the Group 3 fillings, the $\delta^{13} \mathrm{C}$ values of Group $1-2$ calcite were highly variable, ranging from -
$53.8 \%$ to $+31.8 \%$ and they showed systematic variation with depth. The near surface environment high variations within single fillings of up to $39 \%$. The analyzed calcite fillings were mostly
associated with two calcite groups, of which Group 3 represents possible Paleozoic fluid
circulation, based on comparison with similar dated coatings within the Baltic Shield and the
succeeding Group 1-2 fillings represent late-stage, low temperature mineralization and are possibly
late Paleozoic to Quaternary in age. Both generations were associated with pyrite with $\delta^{34} \mathrm{~S}$ values
indicative of bacterial sulfate reduction. The $\delta^{13} \mathrm{C}$ values of calcite, however, were indicative of
geochemical environments which were distinct for these generations. The $\delta^{13} \mathrm{C}$ values of Group 3
calcite varied from -22.1\%o to $+11 \%$, with a distinct peak at $-16 \%$ to $-12 \%$. Furthermore, there
were no observable depth dependent trends in the $\delta^{13} \mathrm{C}$ values of Group 3 calcite. The $\delta^{13} \mathrm{C}$ values of
Group 3 calcite were indicative of organic matter degradation and methanogenesis. In contrast to
the Group 3 fillings, the $\delta^{13} \mathrm{C}$ values of Group $1-2$ calcite were highly variable, ranging from -
$53.8 \%$ to $+31.8 \%$ and they showed systematic variation with depth. The near surface environment

(

2

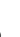

(1)
}

.
.

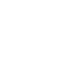

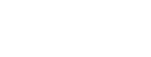
$x_{1}$ 
of $<30 \mathrm{~m}$ (bsl) was characterized by $\delta^{13} \mathrm{C}$ values indicative of degradation of surface derived organic matter, with $\delta^{13} \mathrm{C}$ values ranging from $-30.3 \%$ o to $-5.5 \%$. The intermediate depth of $34-54 \mathrm{~m}$ showed evidence of localized methanotrophic activity seen as anomalously ${ }^{13} \mathrm{C}$ depleted calcite, having $\delta^{13} \mathrm{C}$ values as low as $-53.8 \%$ o. At depths of $\sim 60-400 \mathrm{~m}$, positive $\delta^{13} \mathrm{C}$ values of up to $+31.8 \%$ in late-stage calcite of Group 1-2 indicated methanogenesis. In comparison, high $\mathrm{CH}_{4}$ concentrations in present day groundwaters are found at depths of $>300 \mathrm{~m}$. One sample at a depth of $111 \mathrm{~m}$ showed a transition from methanogenetic conditions (calcite bearing methanogenetic signature) to sulfate reducing (precipitation of pyrite on calcite surface), however, the timing of this transition is so far unclear. The results from this study gives indications of the complex nature of sulfur and carbon cycling in fractured crystalline environments and highlights the usefulness of in situ stable isotope analysis.

\section{Introduction}

Subsurface life and associated geochemical processes usually rely on the circulation of organic and inorganic substrates in groundwater. This is especially true for crystalline bedrock environments, where the bulk of groundwater flow occurs in channels provided by fracture networks. Microbial communities found in these environments are both active and variable (e.g. Bomberg et al., 2015 Hallbeck and Pedersen, 2008; Nyyssönen et al., 2012; Pedersen et al., 2008, 2013). A study by Pedersen et al., (1997) found fossil remains of microbial material in fracture fillings and showed that microbial life in crystalline environments may have ancient roots. Most of dissolved organic matter introduced into the fractured rock via infiltrating waters will be mineralized by aerobic and anaerobic microbial processes, which, in turn, may lead to fracture mineral precipitation (e.g. Drake et al., 2015a, b; Sahlstedt et al., 2013). In fractured rock, early hydrothermal fillings generally dominate fracture mineralizations (Blyth et al., 2000, 2009; Drake and Tullborg, 2009; Sandström and Tullborg, 2009; Sahlstedt et al., 2010). However, late low temperature fillings commonly occur and mineral phases such as calcite can provide an important record of paleofluid circulation in the bedrock (e.g. Drake et al., 2012, 2015a,b; Iwatsuki et al., 2002; Sahlstedt et al., 2010) Groundwater flow is variable and can be slow or sporadic due to tectonic activity related to, for example, 
glacioisostatic movements (e.g. Hutri, 2007) which change flow paths in fractured rock. In addition, the composition of the inflowing groundwater may change with time. This is the case in sites located around the Baltic Sea, where multiple distinct infiltrations events characterize groundwater evolution (Laaksoharju et al., 1999; Pitkänen et al., 2004). Even if these types of external forcing factors are absent, microbial activity has the ability to modify their chemical environment by reactions which otherwise would be impossible or very slow. Therefore, understanding the factors that control microbial activity in the subsurface is of primary importance in understanding geochemical evolution in deep bedrock fractures.

The Olkiluoto island on the western coast of Finland (Fig. 1) is an excellent site to study the geochemical evolution of groundwaters in bedrock fractures. Due to the ongoing site characterization and the construction of a deep geological repository intended to host spent nuclear fuel, cored boreholes have been drilled at the site for various studies. This drill core material has been sampled for the purposes of the current study. The geological history of the site during the Pleistocene and Holocene has been complex, and the bedrock fractures have been affected by several, chemically distinct infiltration events. These include, for example, glacial meltwater intrusions during the retreat of continental ice sheets, brackish water from the Baltic basin and fresh meteoric water infiltration after the area was exposed above sea level (e.g. Posiva, 2013). Consequently, the geochemical composition of infiltrating water has likely varied extensively, which has had an impact on the geochemical conditions in the deep bedrock. Information on these infiltration events has been stored in the chemical and isotopic composition of groundwaters (Posiva, 2013; Stotler et al., 2012) and fracture filling minerals (Sahlstedt et al. 2010; 2013).

Sulfur cycling in bedrock fractures is of special interest in localities where $\mathrm{SO}_{4}{ }^{2-}$-rich waters have been able to infiltrate into the bedrock. At Olkiluoto, $\mathrm{SO}_{4}{ }^{2-}$ containing waters from the Baltic Sea have intruded into the bedrock (Pitkänen et al., 2004; Posiva, 2013) seen today as elevated $\mathrm{SO}_{4}{ }^{2-}$ concentrations in groundwaters in the depth range of 150-300 m (Posiva, 2013). These $\mathrm{SO}_{4}{ }^{2-}$-rich 
waters have been shown to have infiltrated during the Littorina Sea stage of the Baltic Sea (Pitkänen et al., 2004) mainly during its most saline period at around 6000-3000 a (Widerlund and Andersson, 2011). Even earlier Pleistocene events may have introduced $\mathrm{SO}_{4}{ }^{2-}$ into the fractures, including, for example, the marine phase of the Eemian interglacial ca. 130-116 ka ago (Miettinen et al., 2002). Direct evidence for bacterial sulfate reduction (BSR) in bedrock fractures at Olkiluoto has been provided by observations of active microbial sulfate reducers (Haveman et al., 1999; Haveman and Pedersen, 2002; Pedersen et al., 2014), and sulfur isotope signatures of dissolved sulfate (Pitkänen et al., 2004; Posiva, 2013). In addition, recent sulfur isotope studies of fracture bound pyrite indicated that microbial sulfate reduction has been an important process in bedrock fractures repeatedly during the geological history of the site, possibly from the Paleozoic onwards (Sahlstedt et al., 2013).

Some open questions remain about the nature of the sulfate reduction process at Olkiluoto.

Relatively high concentrations of $\mathrm{SO}_{4}{ }^{2-}$ of up to $510 \mathrm{mg} / \mathrm{L}$, remain in the deep groundwater at depths of ca. 150-300 m, in a seemingly stable setting (Posiva, 2013). The reason for this stability is thought to be the lack of organic compounds which could be used by microbes as electron donors in $\mathrm{SO}_{4}{ }^{2-}$ reduction (Pitkänen et al., 2004; Posiva, 2013). However, a compositional boundary between $\mathrm{SO}_{4}{ }^{2-}$ and $\mathrm{CH}_{4}$ containing water masses at a depth of $300 \mathrm{~m}$ appears to be an exception. Along this chemical boundary $\mathrm{HS}^{-}$concentrations are occasionally elevated, indicating that active $\mathrm{SO}_{4}{ }^{2-}$ reduction (Pitkänen et al., 2004) may occur by microbial mediated anaerobic methane oxidation (Pedersen et al., 2008; 2014; Posiva, 2013). Furthermore, Pedersen (2013) experimentally demonstrated the potential coupling of microbial anaerobic oxidation of methane to sulfate reduction at a depth of $327 \mathrm{~m}$ in Olkiluoto. The position of this sulfate reduction zone is well documented in the chemical composition of groundwaters. However, no evidence exists for the past evolution of this interface. 
107 Close to the ground surface, the bedrock fractures were saturated with $\mathrm{SO}_{4}{ }^{2-}$-rich waters during the

108 Littorina Sea stage of the Baltic Sea. $\mathrm{The} \mathrm{SO}_{4}{ }^{2-}$ in the upper $100 \mathrm{~m}$ of bedrock has mostly been

109 diluted by subsequent meteoric infiltration and partly been consumed by bacterial sulfate reduction.

110 Fracture bound pyrite in the upper parts of the bedrock, where $\mathrm{SO}_{4}{ }^{2-}$ concentrations are currently

111 low, indicates that past $\mathrm{SO}_{4}{ }^{2-}$ reduction events have occurred (Sahlstedt et al., 2013).

112 The carbon isotope composition of calcite in the bedrock fractures can be used to examine the

113 substrates involved in sulfate reduction and thus more information can be gained about this

114 important redox process in the bedrock. The aim of this study is to examine carbon cycling in

115 bedrock fractures by analyzing the carbon isotope composition of fracture calcite in situ using

116 secondary ion mass spectrometry (SIMS). The spot analyses reveal a more detailed picture of

117 carbon isotope variability in the calcite fillings and, therefore, provide a more comprehensive

118 picture of the processes involved compared to conventional bulk analyses (cf. Drake et al., 2015b).

119 We especially concentrate on fracture fillings with coexisting calcite and pyrite, where earlier sulfur

120 isotope analyses of pyrite have provided strong evidence for BSR (Sahlstedt et al., 2013).

121 1.1. Isotopic signature of carbon in dissimilatory sulfate reduction

122 BSR is a common process in anaerobic, sulfate rich environments, most notably in marine settings

123 (e.g. Knittel and Boetius, 2009; Megonigal et al., 2005). In BSR, bacteria reduce $\mathrm{SO}_{4}{ }^{2-}$ to $\mathrm{S}^{2-}$, using

124 organic carbon or $\mathrm{H}_{2}$ as an electron donor. Because BSR is associated with a significant kinetic

125 fractionation effect, analyses of the S-isotopic composition of sulfide may be applied to demonstrate

126 the occurrence of bacterial sulfate reduction. The kinetic fractionation factor associated with BSR

127 varies depending on the environment and micro-organisms involved (Detmers et al., 2001). Pure

128 culture studies have shown that for some strains of bacteria the enrichment factor $\varepsilon^{34} \mathrm{~S}_{\text {sulfate-sulfide }}$

129 may be as high as 66\%o (Sim et al., 2011) which is in line with the large, up to $~ 70 \%$ o fractionations

130 observed in nature (e.g. Drake et al., 2015a; Wortmann et al., 2001). As a result, the bacteria tend to 
131 strongly enrich the product sulfide in ${ }^{32} \mathrm{~S}$. If the amount of $\mathrm{SO}_{4}{ }^{2-}$ available for bacteria is limited, the

$132 \delta^{34} \mathrm{~S}$ values of the sulfide will become progressively higher as $\mathrm{SO}_{4}{ }^{2-}$ is consumed in the reaction. In

133 bedrock fractures BSR has been demonstrated by a large variation in the $\delta^{34} S$ values of low

134 temperature pyrite (Drake et al., 2013; Sahlstedt et al., 2013). At Olkiluoto, the $\delta^{34}$ S values of pyrite

135 in bedrock fractures varied from $-50 \%$ to $+82 \%$ (Sahlstedt et al., 2013) and in Laxemar, Sweden,

136 from $-50 \%$ o to $+91 \%$ (Drake et al., 2013). High, positive $\delta^{34} \mathrm{~S}$ values indicate a restricted $\mathrm{SO}_{4}{ }^{2-}$

137 supply in the fracture network (Drake et al., 2013; Sahlstedt et al., 2013)

138 Sulfate reduction and carbon cycling are strongly linked because in the $\mathrm{SO}_{4}{ }^{2-}$-reduction process

139 organic carbon is mineralized and transferred to the dissolved inorganic carbon (DIC) pool. In

140 ocean water the $\delta^{13} \mathrm{C}$ value of dissolved organic carbon (DOC) is typically low; at about $-22 \%$ o

141 (Benner et al., 1997). In soils and aquifers, the $\delta^{13} \mathrm{C}$ value of DOC is more variable, but typically

142 close to $-25 \%$ o (e.g. Clark and Fritz, 1997). Degradation of organic matter will transfer this isotopic

143 signature to the DIC.

144 In environments where organic carbon is mineralized in BSR, the $\delta^{13} \mathrm{C}$ value of DIC depends not

145 only on the bacterial contribution, but also on the other carbon sources adding to the DIC pool. The

146 evolution of carbon isotope composition of DIC is therefore site specific and often complex. At

147 Olkiluoto, the $\delta^{13} \mathrm{C}$ of DIC in the present overburden varies from -27\%o to $-11 \%$, indicating

148 degradation of organic matter and mineral weathering, including dissolution of carbonate minerals

149 in till and near surface fractures (Posiva, 2013). A contribution from ocean water would input DIC

150 with a $\delta^{13} \mathrm{C}$ value close to $0 \%$ (e.g. Veizer et al., 1999). Mixing between these surface-derived

151 carbon sources could therefore lead to $\delta^{13} \mathrm{C}_{\text {DIC }}$ values varying from about $-25 \%$ o to close to $0 \%$ o.

152 Anaerobic oxidation of methane (AOM) by microbes has been linked with sulfate reduction in

153 marine sediments, where it forms an important $\mathrm{CH}_{4}$ consuming zone at the $\mathrm{SO}_{4}{ }^{2-} / \mathrm{CH}_{4}$ interface (e.g.

154 Barnes and Goldberg, 1976). Even though a zone of $\mathrm{CH}_{4}$ oxidation and $\mathrm{SO}_{4}{ }^{2-}$ reduction is often 
distinct in geochemical profiles (Barnes and Goldberg, 1976; Martens and Berner, 1974; Reeburgh, 1976), open questions remain concerning the microbial community responsible for the AOM (e.g. Antler et al., 2014). In addition to marine sediments, it is possible to find AOM also in other environments where $\mathrm{SO}_{4}{ }^{2-} / \mathrm{CH}_{4}$ interfaces are found, such as in deep bedrock fractures (Kotelnikova, 2002). In a recent study, Drake et al. (2015) were able to connect BSR to AOM in deep bedrock fractures. Due to the low $\delta^{13} \mathrm{C}$ values of methane $\left(\delta^{13} \mathrm{C}_{\mathrm{CH} 4}<-50 \%\right.$ o for bacterial $\mathrm{CH}_{4}$, Whiticar, 1999), as well as the kinetic fractionation effect of microbial oxidation which further enriches the forming $\mathrm{CO}_{2}$ in ${ }^{12} \mathrm{C}$ (Alperin et al., 1988; Whiticar and Faber, 1986; Whiticar, 1999), AOM will introduce significantly ${ }^{13} \mathrm{C}$-depleted carbon into the DIC pool. Thus, anomalously low $\delta^{13} \mathrm{C}_{\text {DIC }}$ values are usually connected to $\mathrm{CH}_{4}$ oxidation. If carbonate minerals precipitate, they will be characterized by low $\delta^{13} \mathrm{C}$ values, providing an archive of methane oxidation events. For example, at the Swedish site of Laxemar, fracture calcite with $\delta^{13} \mathrm{C}$ values as low as $-125 \%$ o have been found, indicating oxidation of $\mathrm{CH}_{4}$ deep in the bedrock (Drake et al., 2015b).

\section{Study site}

\subsection{Geology and hydrogeochemical characteristics}

The study site is located on an island just off the western coast of Finland and ca. $10 \mathrm{~km}$ north from the city of Rauma. The bedrock of the area is composed of metamorphosed supracrustal rocks, which belong to the Paleoproterozoic Svecofennian bedrock domain (Fig 1). The main rock types on the island are high-grade metamorphic epiclastic and pyroclastic sediments, presently occurring as gneisses and migmatitic gneisses (Fig. 1b). A detailed description of the Olkiluoto bedrock can be found in Kärki and Paulamäki, (2006). The Laitila rapakivi granite batholith and its satellite, the Eurajoki rapakivi stock are located to the east and south of the study area. The rapakivi granite intrusions are Mesoproterozoic, and the main phase of the intrusion is $1583 \pm 3$ Ma old (Vaasjoki, 1996). The Satakunta Formation is located northeast of the site, a formation composed of mainly 
sandstone deposited into an elongated fault bounded area (Kohonen and Rämö, 2005). The

180 sandstone formation continues into the Baltic Sea basin (Winterhalter, 1972) and it is estimated to be ca. 1600 Ma old (Klein et al., 2014).

182

183

184

Groundwaters at Olkiluoto are approximately horizontally stratified according to their chemical characteristics and composed of mixtures of waters derived from different sources (Pitkänen et al. 2004; Posiva, 2013). Deviations from the horizontal occur along hydraulically active zones (Fig. 2a). In the upper $100 \mathrm{~m}$ from ground surface, the groundwaters are $\mathrm{HCO}_{3}{ }^{-}$-type, changing from fresh (total dissolved solids, TDS $<1 \mathrm{~g} / \mathrm{L})$ to brackish $(1<\mathrm{TDS}<10 \mathrm{~g} / \mathrm{L})$ with increasing depth. They are relatively young $(<2500 a)$ and composed of mixtures of fresh meteoric waters, Baltic Sea water and fresh evaporated water from the Korvensuo reservoir, a man made small reservoir in the middle of the island, with water derived from the nearby Eurajoki river. At the depth range of 100-300 m the waters are of the brackish $\mathrm{SO}_{4}{ }^{2-}$-type. The $\mathrm{SO}_{4}{ }^{2-}$-concentrations range from $123-510 \mathrm{mg} / \mathrm{L}$ (Posiva, 2013). The $\mathrm{SO}_{4}{ }^{2-}$-rich waters infiltrated during the Littorina Sea stage of the Baltic Sea (beginning at 8500 a, Björk, 2008) replacing and mixing with less saline subglacial groundwaters and/or glacial melt waters (Posiva, 2013). Due to mixing with the melt waters with very low $\delta^{18} \mathrm{O}$ values (estimated $\delta^{18} \mathrm{O}$ value -22\%o, Pitkänen et al., 2004) and Littorina Sea water (estimated $\delta^{18} \mathrm{O}$ value $-4.7 \%$, Pitkänen et al., 2004), the $\delta^{18} \mathrm{O}$ values of the $\mathrm{SO}_{4}{ }^{2-}$-type groundwaters are locally very low, down to $-15.9 \%$ (Posiva, 2013). This meltwater dilution also affects the brackish Cl-type groundwaters. At depths of $300 \mathrm{~m}$ and deeper, the groundwaters are of the brackish Cl-type, turning to saline at depths of $>400 \mathrm{~m}$. The brackish Cl-type groundwaters are considered to be diluted ancient brine (TDS $>100 \mathrm{~g} / \mathrm{L}$ ), present at depths of $>1 \mathrm{~km}$ in the bedrock of Olkiluoto (Posiva, 2013). The brackish $\mathrm{Cl}$ and saline water types have a high $\mathrm{Br} / \mathrm{Cl}$ ratio, indicating they possibly originate from evaporitic residual fluids (Pitkänen et al., 2004; Posiva, 2013). The saline and brackish waters (or the original brine) have been diluted by fresh water infiltrations with a colder climate signature compared to the present day and have also been affected by water-mineral 
interaction (Posiva, 2013). For further details on the composition and evolution of the Olkiluoto groundwaters, the reader is referred to Posiva, (2013) and Pitkänen et al., (2004).

Active microbial communities have been found at Olkiluoto (Bomberg et al., 2015; Haveman et al., 1999; Haveman and Pedersen, 2002; Nyyssönen et al., 2012; Pedersen et al., 2014; Posiva, 2013). Within the current geochemical environment, different microbial communities dominate at different depths (Pedersen et al., 2014; Posiva, 2013). Sulfate reducing bacteria (SRB) are found at both shallow depths and at the depth range of 200-400 m (Pedersen et al. 2014). SRB are most numerous at the interface of the $\mathrm{SO}_{4}{ }^{2-}$-rich and $\mathrm{CH}_{4}$-containing groundwaters (Pedersen et al., 2014). At the same depth range there is also a peak in sulfide concentrations (Posiva, 2013). Microbial studies conducted at Olkiluoto strongly suggest that sulfate reduction is significant at this depth and related to the occurrence of both $\mathrm{SO}_{4}{ }^{2-}$ and $\mathrm{CH}_{4}$ in the water mass (Posiva, 2013). A possible pathway for $\mathrm{SO}_{4}{ }^{2-}$ reduction at the $\mathrm{SO}_{4}{ }^{2-} / \mathrm{CH}_{4}$ interface is anaerobic methane oxidation, where microbes use $\mathrm{CH}_{4}$ and possibly also other short chained hydrocarbons as electron donors (Posiva, 2013). At shallower depths, where $\mathrm{SO}_{4}{ }^{2-}$-reducing bacteria are also encountered, electrons are likely provided by organic carbon compounds transferred into the fractures with the infiltrating waters.

In addition to microbial studies, the isotopic composition of $\mathrm{SO}_{4}{ }^{2-}$ in groundwaters indicates that bacterial sulfate reduction has occurred at Olkiluoto. In the overburden and the shallower parts of the bedrock, $\mathrm{SO}_{4}{ }^{2-}$ concentration is low, typically $<100 \mathrm{mg} / \mathrm{L}$, and derived from oxidation of organic material and sulfide minerals (Posiva, 2013). Most of the $\mathrm{SO}_{4}{ }^{2-}$ in the Olkiluoto groundwaters is concentrated at the depth range of 100-300 $\mathrm{m}$ and represent the remains from the infiltration of the Littorina Sea water. At these depths, the $\mathrm{SO}_{4}{ }^{2-}$ concentrations are on average $356 \mathrm{mg} / \mathrm{L}$. Sulfur and oxygen isotope compositions of the dissolved $\mathrm{SO}_{4}{ }^{2-}$ indicate that BSR has occurred (Posiva, 2013). 
228 For example, $\delta^{34} \mathrm{~S}$ values as high as $+36 \%$ are found at depths of $>150 \mathrm{~m}$ and the average value of 229 the Littorina derived $\mathrm{SO}_{4}{ }^{2-}$ is $+25.8 \%$ (Pitkänen et al., 2004). Similarly, the $\delta^{18} \mathrm{O}$ values of $\mathrm{SO}_{4}{ }^{2-}$ have increased due to BSR, interpreted from the covariation of $\delta^{34} \mathrm{~S}$ and $\delta^{18} \mathrm{O}$ values in $\mathrm{SO}_{4}{ }^{2-}$

231 (Posiva, 2013).

In overburden and shallow bedrock, the $\delta^{13} \mathrm{C}$ values of DIC range from $-27.5 \%$ to $-5.8 \%$ (Fig. 2).

In the fresh and brackish $\mathrm{HCO}_{3}{ }^{-}$-type groundwaters the $\delta^{13} \mathrm{C}_{\text {DIC }}$ values have a narrower range, from $-18.6 \%$ o to $-12.2 \%$ (Fig. 2, Posiva, 2013). The $\delta^{13} \mathrm{C}_{\text {DIC }}$ values indicate input from the degradation of organic carbon, which in the upper parts of the bedrock is the most likely substrate used in BSR. However, minor amounts of $\mathrm{CH}_{4}$ oxidation may occur which is not shown in the $\delta^{13} \mathrm{C}_{\text {DIC }}$ values of the mixed DIC pool. The DIC content of the deep groundwaters is low, typically $<20 \mathrm{mg} / \mathrm{L}$ at depths of $>100 \mathrm{~m}$, and therefore, $\delta^{13} \mathrm{C}_{\mathrm{DIC}}$ data from the deep groundwaters are scarce. Even though other geochemical data and microbial studies indicate that anaerobic methane oxidation occurs, it is not reflected in the few $\delta^{13} \mathrm{C}_{\mathrm{DIC}}$ values obtained from these depths. One very low $\delta^{13} \mathrm{C}$ value of $36 \%$ has been analyzed from the $\mathrm{SO}_{4}{ }^{2-}$-type waters, representing the only $\mathrm{C}$ isotopic indication of possible $\mathrm{CH}_{4}$ oxidation (Posiva, 2013). Typically, at depths $>100 \mathrm{~m}$, the $\delta^{13} \mathrm{C}_{\text {DIC }}$ values vary between $-25 \%$ and $-10 \%$ (Posiva, 2013).

\subsection{Mineralogical evidence on sulfate reduction at Olkiluoto}

Fracture filling calcite was divided into five groups according to mineral associations, morphology and sequence of precipitation (Sahlstedt et al., 2010). Pyrite is associated with all of the calcite groups (Sahlstedt et al., 2010; 2013). Group 1-2 calcite fillings represent the latest mineral fillings in the fracture surfaces and are composed of small euhedral crystals or thin platelets (Group 1) which may contain small amounts of silicate impurities (Group 2). Group 1-2 calcite fillings precipitated at low temperatures, indicated by the lack of two phase (liquid and vapor) primary inclusions $\left(<80^{\circ} \mathrm{C}\right.$, Roedder, 1984). The isotopic composition of group 1-2 calcite and pyrite have 
more variation, compared to the massive $\sim 1-20 \mathrm{~mm}$ thick calcite growth layers classified into groups 3, 4 and 5 (Sahlstedt et al. 2010; 2013).

254

Mineralogical evidence of past redox conditions has been obtained from fracture mineral studies (Sahlstedt et al., 2010; 2013). The $\delta^{13} \mathrm{C}$ values of late-stage fracture filling calcite (Groups 1-2) indicate that a methanogenetic environment prevailed earlier at a shallower depth compared to the current situation (Sahlstedt et al., 2010). High $\delta^{13} \mathrm{C}$ values indicate methanic conditions at depths of around $50 \mathrm{~m}$, when, in comparison, the $\mathrm{CH}_{4}$ concentrations presently begin to rise at depths of ca. $300 \mathrm{~m}$ in the fracture network (Posiva, 2013). Low $\delta^{13} \mathrm{C}$ values from fracture calcite, analyzed by conventional methods, which could be related to methane oxidation have been very rare, with only one Group 1 sample at the depth of $16 \mathrm{~m}$ having a $\delta^{13} \mathrm{C}$ value of $-30.3 \%$ (Sahlstedt et al., 2010).

Evidence from the $\delta^{34} \mathrm{~S}$ values of fracture pyrite have indicated a complex system of $\mathrm{SO}_{4}{ }^{2-}$ reduction and this is reflected in the extensive range of $\delta^{34} \mathrm{~S}$ values analyzed form late-stage pyrite, which is from $-50 \%$ o to $+78 \%$ o (Sahlstedt et al., 2013). Sulfate reduction has in certain fractures proceeded close to complete consumption of the $\mathrm{SO}_{4}{ }^{2-}$, as evidenced by highly positive $\delta^{34} \mathrm{~S}$ values of up to $+78 \%$ o for Group 1 (Sahlstedt et al., 2013). In some fracture pyrite grains, reversals of the $\delta^{34} \mathrm{~S}$ trends have indicated repeated infiltrations of new $\mathrm{SO}_{4}{ }^{2-}$ after the original $\mathrm{SO}_{4}{ }^{2-}$ had been largely consumed (Sahlstedt et al., 2013). These trends were thought to reflect the heterogenic flow properties of the bedrock, possibly affected by glacioisostatic movements.

Interestingly, the $\delta^{34} \mathrm{~S}$ values of pyrite in Group 3 showed a similar distribution as those in the latestage, Group 1-2 pyrite, varying from $-40 \%$ o to $+82 \%$ (Sahlstedt et al., 2013). Group 3 fillings formed at moderate temperatures (Sahlstedt et al., 2010; 2013) and were thought to be related to Paleozoic burials, during which wide areas of the Fennoscandian Shield were thought to have been covered by sedimentary deposits originating from the eroding Caledonides (Larson and Tullborg, 1998; Larson et al., 1999; Tullborg et al., 1995). Group 3 fillings have similar characteristics as 
fracture fillings in different localities within the Fennoscandian Shield (Sahlstedt et al., 2013), for

277 which isotope geochronometric data indicates fluid circulation especially in the Silurian and early 278 Devonia (Drake et al., 2009; Sandström et al., 2009; Alm et al., 2005). The wide variation in the $279 \delta^{34}$ S values of the pyrite suggests that BSR was active in the fractures during the precipitation of 280 Group 3 fillings (Sahlstedt et al., 2013).

281 3. Materials

282 Calcite samples were selected from the drill core material obtained from Olkiluoto. Primary 283 selection was aimed at the samples for which S-isotope data were available (Sahlstedt et al., 2013) and included 23 fracture fillings in total. Additional samples were selected based on calcite type and depth range (six samples) and from fractures with a black pigment, possibly representing early stages of sulfide precipitation (three samples). The samples were collected from 22 different drill cores obtained from bore drillings at the central and eastern parts of the island (Fig. 1b) and cover a depth range from $5 \mathrm{~m}$ (below sea level, b.s.l.) to $527 \mathrm{~m}$ (b.s.l.). The samples also allow comparison between the Group 1-2 and Group 3 fillings, which both had indicated the influence of BSR in a previous study (Sahlstedt et al., 2013).

A cross section of calcite fillings was needed for the in situ carbon isotope analysis. The samples were prepared from 2-4 mm thick rock sections, cut perpendicular relative to the fracture surface. Suitable subsamples were selected from the sections, containing typically a few mm thick areas of the filling, which was cut from the rock slides and attached on epoxy buttons. Standards were attached to the same sample buttons prior to SIMS analyses. 
298 Prior to SIMS analyzes, the calcite samples were analyzed with an electron microscope at the

299 Geological Survey of Finland, in order to obtain back scattered electron images (BEI) of the

300 samples. Possible compositional variations of the calcite can be observed in the BEI, which can

301 then be used in the selection of the spots for the C-isotope analysis. The samples were analyzed

302 under low vacuum conditions to avoid the need for sample coating.

304 Carbon isotope analyses were performed in several analytical sessions using a CAMECA IMS 1280 large geometry SIMS at the NordSIM facility in Stockholm, Sweden. A critically focused ca. $3 \mathrm{nA}$

$\mathrm{Cs}^{+}$primary beam with $20 \mathrm{keV}$ impact was used to sputter the sample, and a low-energy electron

flooding gun was used for charge compensation. The primary beam was homogenized using a 10 $\mu \mathrm{m}$ raster, resulting in a ca. $15 \mu \mathrm{m}$ analytical spot. Each analysis consisted of an initial pre-sputter over a rastered $20 \mu \mathrm{m}$ area to remove the gold coating, followed by centering of the secondary beam in the field aperture (field of view on the sample of $30 \mu \mathrm{m}$ with $90 \mathrm{x}$ magnification transmission ion optics). Secondary ion signals were measured in the multicollector mode using a Faraday detector for ${ }^{12} \mathrm{C}^{-}\left(\mathrm{ca} .2 \times 10^{7} \mathrm{cps}\right)$, and an ion counting electron multiplier for ${ }^{13} \mathrm{C}^{-}$at a mass resolution of ca. 4000, sufficient to resolve ${ }^{13} \mathrm{C}$ from ${ }^{12} \mathrm{C}^{1} \mathrm{H}$. A within run correction was made for EM gain drift using the pulse height analysis curve. The secondary magnet field was locked at high stability using an NMR field sensor operating in regulation mode. All pre-sputter, beam centering and data acquisition steps were automated in the run definition. Typical internal precision obtained for individual run ${ }^{13} \mathrm{C} /{ }^{12} \mathrm{C}$ ratios from twenty-four cycles of 4 -second integrations was ca. $0.2 \%$ o

318 (SE). The sample chamber vacuum was maintained at $<2 \times 10^{-8}$ mbar.

319 Fully automated sequences comprised two measurements of the reference carbonate, Brown Yule 320 Marble calcite (BYM, kindly provided by J. Craven, University of Edinburgh), bracketing six measurements of unknown targets. The regularly interspersed BYM measurements were used to 
correct measured isotope ratios for any drift during the analytical session (typically a cubic polynomial fit was made to the standard analyses) and for instrumental mass fractionation (IMF), assuming $\delta^{13} \mathrm{C}_{\mathrm{PDB}}=-2.28 \%$ (J. Craven, personal communication). External precision on $\delta^{13} \mathrm{C}$ was $<0.3 \%$ (SD). In total, 322 unknown target spots were measured. The results are reported against the Vienna Pee Dee Belemnite (VPDB) standard, in per mil, using the $\delta$-notation defined as:

$\delta^{13}$ Csample $=\left[\left({ }^{13} \mathrm{C} /{ }^{12}\right.\right.$ Csample $\left.) /\left({ }^{13} \mathrm{C} /{ }^{12} \mathrm{Cstandard}-1\right)\right] \times 1000$ Eq. (1)

\section{Results}

The $\delta^{13} \mathrm{C}$ values of calcite ranged from $-53.8 \%$ o to $+31.6 \%$ (Table S1 and S2 in the Supplementary Material). The highest and the lowest $\delta^{13} \mathrm{C}$ values occurred in the fracture fillings of the upper 110 $\mathrm{m}$ of bedrock and were associated with the youngest fracture calcite generations. The $\delta^{13} \mathrm{C}$ values also varied extensively within a single calcite filling, by up to $38.6 \%$ (Table S1).

The $\delta^{13} \mathrm{C}$ values of the calcite fillings were divided into groups which follow the sequence of calcite generations at Olkiluoto. The most recent calcite Groups 1 and 2 had the largest variations in the $\delta^{13} \mathrm{C}$ values, from $-53.8 \%$ o to $+31.6 \%$ (Fig. 3). Similar highly positive $\delta^{13} \mathrm{C}$ values had been reported from bulk sample analysis of Olkiluoto calcite fillings in a previous study (Sahlstedt et al. 2010), but the highly negative $\delta^{13} \mathrm{C}$ values had not been reported in earlier studies (Fig. 3, Table S1). The low (<-30\%o $\delta^{13} \mathrm{C}$ values were restricted to two fracture fillings, one of which contained calcite with anomalously negative $\delta^{13} \mathrm{C}$ values of $<-50 \%$. The $\delta^{13} \mathrm{C}$ values of calcite in Group 3 showed less variation, from $-22.1 \%$ o to $+11 \%$ (Table S1). Also in Group 3, calcite fillings showed large variations in the $\delta^{13} \mathrm{C}$ values within single fillings, spanning a range of $21.0 \%$.

Figure 4 presents the isotope composition of the calcite with respect to sample depth. The $\delta^{13} \mathrm{C}$ values of Group 1-2 calcite had a relatively narrow range in the upper parts of the bedrock, ranging from $-22.5 \%$ o to $-6.9 \%$ at $>34 \mathrm{~m}$, but varied from highly negative to values close to $0 \%$ o between 34 and $61 \mathrm{~m}$. The lowest $\delta^{13} \mathrm{C}$ values were present only locally in some fillings (Fig. 5). Below $61 \mathrm{~m}$, 
positive $\delta^{13} \mathrm{C}$ values were found in several fillings. At the depth of $102 \mathrm{~m}$ the highest $\delta^{13} \mathrm{C}$ value reached $+31.6 \%$ o (Fig. 4 ). The $\delta^{13} \mathrm{C}$ values of Group 3 calcite varied from $-22.1 \%$ o to $+11.0 \%$ o.

348 Compared to Group 1-2 calcite fillings, the $\delta^{13} \mathrm{C}$ values of Group 3 calcite fillings had a smaller

349 range and did not show similar distinct variation with depth (Fig. 4). At depths of $>297 \mathrm{~m}$, the $\delta^{13} \mathrm{C}$

350 values of Group 1-2 and Group 3 calcite showed a similar range.

351 For comparison, two samples were analyzed from the earliest calcite fillings presented by Group 4 352 and Group 5. Within these samples, the variation the $\delta^{13} \mathrm{C}$ values was limited, spanning from $35313.7 \%$ o to $-2.4 \%$ in Group 5 and from $-13.9 \%$ o to $-13.4 \%$ in Group 4 (Table S1).

6. Discussion

The notably large range of $85 \%$ in the $\delta^{13} \mathrm{C}$ values of the calcite fillings clearly indicates the influence of multiple C-sources in deep groundwaters. Furthermore, this variation mostly characterizes Group 1-2 calcite (Fig. 3), suggesting that it reflects processes occurring at low temperatures. Figure 4 illustrates the fact that the $\delta^{13} \mathrm{C}$ values of Group 1-2 calcite show a systematic variation with depth, which is not seen in Group 3 calcite (Fig. 4). Both Group 1-2 and values (Fig. 6), which indicates isotopic effects caused by kinetic fractionation in BSR (Sahlstedt et al., 2013). The variation patterns in the $\delta^{13} \mathrm{C}$ values of the associated calcite, however, bring up distinct differences in associated microbial processes. Figure 6 also shows the carbon isotope data from conventional analyses (Table S3 in the Supplementary Material) gathered from Olkiluoto. established by the bulk data, but the conventional analyses are able to hide important details of the isotopic variation (Fig. 6). 
The $\delta^{13} \mathrm{C}$ values of late-stage calcite (Group 1-2) at depths of $<34 \mathrm{~m}$ vary from $-30.3 \%$ o to $-5.5 \%$ o (Fig. 4), with most values being between $-12 \%$ and $-20 \%$. The low $\delta^{13} \mathrm{C}$ values indicate input from the degradation of surface derived organic matter. Based on the recent geological history of the site, the organic carbon could have been infiltrated from either terrestrial or marine sources. High concentrations of $\mathrm{SO}_{4}{ }^{2-}$ have been available only when the area was submerged under sea water, because of the lack of sulfate minerals in the bedrock and in the overlaying Quaternary sediments (Posiva, 2013). The marine episodes include the brackish Littorina Sea stage in the Holocene (Björk, 2008) and an earlier marine connection during the Eemian interglacial (Miettinen et al., 2002). It is plausible that organic matter used by BSR has been partly derived from the infiltrating $\mathrm{SO}_{4}{ }^{2-}$-rich waters. During the fresh water stages, the input of $\mathrm{SO}_{4}{ }^{2-}$ has been reduced, limiting the progress of BSR.

Locally, $\delta^{13} \mathrm{C}$ values as high as $-5.5 \%$ were recorded in calcite from the shallow bedrock fractures.

Such high values indicate that, in addition to organic matter degradation, also sources less depleted in ${ }^{13} \mathrm{C}$ were added to the DIC pool. During the brackish Littorina Sea stage, the $\delta^{13} \mathrm{C}_{\mathrm{DIC}}$ value of the infiltrating brackish water has been estimated to be $-1 \%$ (Pitkänen et al., 2004). In the Eemian, Fennoscandia was an island due to a connection to the North Atlantic and to the Barents Sea (Miettinen et al., 2002), and the $\delta^{13} \mathrm{C}_{\text {DIC }}$ was ca. 1\%o (Poore et al., 2006). Marine DIC contribution could thus explain the variation in the $\delta^{13} \mathrm{C}$ values of calcite. The $\delta^{18} \mathrm{O}$ values of the (bulk) calcite

391 (Sahlstedt et al., 2010, 2013; Table S3), do not, however, suggest precipitation from Littorina or ocean water, as this would have been seen as $\delta^{18} \mathrm{O}$ values of about $-5 \%$ (PDB) or higher in the calcite, depending on the precipitation temperature. Nevertheless, a possible contribution from a 
marine water source cannot be ruled out based on the $\delta^{18} \mathrm{O}$ values of the calcite, as the marine

395

396

397

398

399

400

401

402

403

404

405

406

407

408

409

410

411

412

413

414

415

416

417 oxygen isotope signature may have been masked by mixing with fresh waters during infiltration (decreasing the $\delta^{18} \mathrm{O}$ value of the source water) or by the bulk analysis of the calcite material. In situ oxygen isotope data on the calcite fillings may have shed some additional light on the issue, but these were, unfortunately, not measured. Another possible source for ${ }^{13} \mathrm{C}$-enriched carbon is the dissolution of old carbonate minerals in the overburden or in the upper parts of the fracture network. Recycling of old carbonate material can be assumed to dominate in cases when the island was exposed and uplifted above the sea level and the infiltrating waters were of meteoric origin.

\subsubsection{Methane}

Two shallow fracture fillings at depths of $34-54 \mathrm{~m}$ show unusually low $\delta^{13} \mathrm{C}$ values. The anomalously low $\delta^{13} \mathrm{C}$ values of $-53.8 \%$ (Fig. 5a), at a depth of $34 \mathrm{~m}$, clearly indicate input from oxidation of methane (cf. Whiticar, 1999). Additionally, at the depth of $54 \mathrm{~m}$, a calcite filling had $\delta^{13} \mathrm{C}$ values as low as $-36.5 \%$ (Fig. $5 b$ ), which is lower than is typically expected for oxidation of organic matter (cf. Clark and Fritz, 1997) and suggests a mixed source with a contribution from $\mathrm{CH}_{4}$ oxidation. Calcite fillings with a $\mathrm{CH}_{4}$ signature showed $>25 \%$ variation in $\delta^{13} \mathrm{C}$, and unusually low values were observed only locally (Fig. 5), indicating that the source of carbon has fluctuated during the precipitation of the calcite fillings. The highest $\delta^{13} \mathrm{C}$ values of calcite in these fractures were from $-15.3 \%$ o to $-10.9 \%$ (Fig. 4), which is similar to the $\delta^{13} \mathrm{C}$ values of calcite in the upper parts of the fractured bedrock. The large range in the $\delta^{13} \mathrm{C}$ values at these depths could be attributed to variable contributions of methane derived carbon. As a whole, the contribution from $\mathrm{CH}_{4}$ oxidation seems to have been minor and restricted to a few fractures.

Anaerobic methanotrophy is the dominant sink for $\mathrm{CH}_{4}$ in modern marine sediments. The process is operated by a consortium of methane-oxidizing archaea and sulfate-reducing bacteria (Hinrichs and Boetius, 2002) and can also operate in other environments where a sulfate-methane interface is 
418 found (Drake et al., 2015b; Kotelnikova, 2002). The sulfur isotope data from fracture pyrite indicate 419 that there was BSR at shallow depths of $<34 \mathrm{~m}$ in the bedrock fractures (Sahlstedt et al., 2013), and 420 thus also anoxic conditions. Calcite fillings with methane oxidation derived carbon also contained 421 pyrite as seen in Fig 5a, with sulfur isotopic evidence for BSR (Sahlstedt et al., 2013), suggesting a 422 connection between BSR and methane oxidation.

423 Highly positive $\delta^{13} \mathrm{C}$ values of fracture calcite were found at depths of $>100 \mathrm{~m}$ (Fig. 4), but $\delta^{13} \mathrm{C}$ 424 values close to $0 \%$ are found already at depths of $61 \mathrm{~m}$ (Table S1, Sahlstedt et al., 2010). The 425 positive $\delta^{13} \mathrm{C}$ values indicate that the calcite precipitated from a DIC pool which was enriched in $426{ }^{13} \mathrm{C}$. Enrichment of ${ }^{13} \mathrm{C}$ in low temperature environments is commonly caused by microbial methanogenesis (e.g. Irwin et al., 1977). Due to large kinetic fractionation associated with microbial methanogenesis (e.g. Whiticar, 1999), the residual $\left(\mathrm{CO}_{2}\right.$ reduction pathway) or product $\mathrm{CO}_{2}$ (fermentation pathway) is enriched in ${ }^{13} \mathrm{C}$ (Whiticar et al., 1986). As a result, calcite precipitating in this environment would have high $\delta^{13} \mathrm{C}$ values (Sahlstedt et al. 2010).

433 Group 3 calcite fillings, having $\delta^{13} \mathrm{C}$ values ranging from $-22.1 \%$ o to $+11.0 \%$, predate Group $1-2$ 434 calcite, which is indicated by the sequence of mineral formation in fractures. Figure 3 shows the 435 distribution of the $\delta^{13} \mathrm{C}$ values of Group 3 fillings, and the prevalence of low values of the fillings indicate that the main carbon source was degradation of organic matter. The depth distribution of 437 the $\delta^{13} \mathrm{C}$ values of Group 3 calcite suggests that waters containing organic compounds circulated to 438 depths of at least $550 \mathrm{~m}$. In contrast to Group 1-2 fillings, Group 3 fillings do not show 439 anomalously low $\delta^{13} \mathrm{C}$ values resulting from methanotrophic carbon input. The $\delta^{34} \mathrm{~S}$ values of pyrite of the same fillings indicated BSR, similar to Group 1-2 fillings (Sahlstedt et al., 2013). Therefore, 
441 the $\mathrm{C}$ isotope composition of Group 3 calcite fillings suggests that bacteria used surface derived 442 organic matter as substrates in $\mathrm{SO}_{4}{ }^{2-}$ reduction.

445 Group 3 fillings, and the late-stage Group 1-2 fillings, have both been associated with environments 446 influenced by biogenic activity. Fluid inclusion data, although limited in number, indicate that 447 Group 3 fillings crystallized at moderate temperatures $\left(\mathrm{T}_{\mathrm{h}}=50-90{ }^{\circ} \mathrm{C}\right.$, Sahlstedt et al., 2010), high 448 salinity fluids (Sahlstedt et al., 2010; 2013). A high salinity, moderate temperature $\left(\mathrm{T}_{\mathrm{h}}=70-100{ }^{\circ} \mathrm{C}\right)$ 449 fluid type was earlier reported by Blyth et al. (2000). It was suggested (Sahlstedt et al. 2013) that the Group 3 fillings were related to the Paleozoic event of Caledonian foreland basin stage (Larson and Tullborg, 1998; Larson et al., 1999), which caused active fracture filling formation in large areas within the Fennoscandian Shield, as shown by the direct dating of minerals in similar assemblages as Group 3 at Olkiluoto (Drake et al., 2009; Sandström et al., 2009; Alm et al., 2005). Relatively little is known about the Paleozoic sedimentary coverage in Finland, because knowledge of these deposits is mostly based on indirect evidence (Kohonen and Rämö, 2005). Large parts of Finland are thought to have been covered by sediments of the Cambrian to Silurian in age (Kohonen and Rämö, 2005), and later by a thicker succession of clastic material from the eroding Caledonides

458 (Larson et al., 1999). In Sweden, the Paleozoic sedimentary cover is thought to have acted as a 459 source of organic matter and sulfur for the water circulating in the bedrock fractures (Drake and 460 Tullborg, 2009; Sandström and Tullborg, 2009). The $\delta^{13} \mathrm{C}$ values of Group 3 calcite fillings indicate 461 a relatively uniform DIC pool, with a significant contribution of carbon from the degradation of organic matter (Fig. 3) associated with BSR (Fig. 6). Overlaying deposits containing organic matter and sulfate were a likely source of substrates for BSR. 
464 Group 3 fillings were followed by the precipitation of Group 1-2 fillings on open fracture surfaces.

465 No isotope geochronometric data so far exist from the fillings, and therefore it is difficult to ascertain the true age difference between presumably Paleozoic Group 3 fillings and the succeeding

467 late-stage fillings of Groups 1-2, which often form platelets of euhedral crystals on top of continuous Group 3 fillings (Sahlstedt et al. 2010). A low temperature environment has prevailed in the fracture bedrock of Olkiluoto probably for about tens of millions of years (Kohonen and Rämö, 2005) and Group 1-2 may partly represent the final stages of Paleozoic circulation and the following long period of low temperature fluid circulation. The drastic change in the isotopic composition of the fillings going from Group 3 to Group 1-2, gives an indication of a change in the paleofluid compositions (this study, Sahlstedt et al., 2010) and evolution to a somewhat more complex system with regards to carbon circulation. Variations in the $\delta^{13} \mathrm{C}$ values of calcite combined with the variations in the $\delta^{34}$ S values of associated pyrite (Fig. 6, Sahlstedt et al., 2013) demonstrate that the upper parts of the bedrock have been geochemically active. The largest variation in the $\delta^{34} \mathrm{~S}$ values of late-stage (Group 1-2) pyrite occur in the upper $25 \mathrm{~m}$ of the fractured bedrock (Fig. 6). The carbon isotope data of associated calcite indicate input from degradation of organic matter, thus showing that input of organic carbon from the ground surface could sustain active $\mathrm{SO}_{4}{ }^{2-}$ reduction in the shallow bedrock and that this input was sufficient to produce near complete reduction of the $\mathrm{SO}_{4}{ }^{2-}$ in the fractures. Evidence for clear methanotrophic activity, possibly associated with BSR, is found at the depth of $34 \mathrm{~m}$, and a potential methanotrophic signal at the depth of $54 \mathrm{~m}$. This data shows that $\mathrm{CH}_{4}$ oxidation has affected restricted parts of the fractures in the upper parts of bedrock and could only have made a very minor contribution to BSR.

There is a notable change from negative $\delta^{13} \mathrm{C}$ values to positive ones at the depth range of 50-60 m, which indicates a transition to a methanogenetic environment at this depth range (Fig. 6). Positive $\delta^{13} \mathrm{C}$ values are common in the latest fracture calcite precipitates at depths $>60 \mathrm{~m}$ (Fig. 4, 6). In one fracture at the depth of $111 \mathrm{~m}$, the fracture surface of calcite with methanogenetic signature $\left(\delta^{13} \mathrm{C}\right.$ 
up to $+12.1 \%$ o, Table S1) was covered by tiny pyrite crystals indicating that methanogenetic

490 conditions were followed by sulfidic conditions with active BSR. Comparing mineralogical

491 observations to the current groundwater environment provides further insight for this change

492 observed in the mineralogical data.

6.5. Evolution of the groundwater system

The current groundwater environment is characterized by redox boundaries with active microbial communities; the first one occurs in the overburden and shallow bedrock where dissolved oxygen is consumed and the second one is at depths of $\sim 300 \mathrm{~m}$ in the deep bedrock where $\mathrm{SO}_{4}{ }^{2-}$ and deeper $\mathrm{CH}_{4}$-containing groundwaters meet (Pedersen et al., 2014; Pitkänen et al., 2004; Posiva, 2013,). The $\delta^{13} \mathrm{C}$ values are variable in the overburden and in the shallow bedrock indicating that multiple processes are involved in transferring carbon into the DIC pool (Fig. 2, Posiva 2013). The $\delta^{13} \mathrm{C}$ values of the DIC in deep groundwaters, however, show no clear depth dependent trends and the change from a sulfidic to a methanic environment is not apparent in this data (Fig. 4). Instead, the occurrence of increased $\mathrm{HS}^{-}$concentrations and activity of sulfate reducing bacteria are indicators of the redox transition at the $\mathrm{SO}_{4}{ }^{2-} / \mathrm{CH}_{4}$ interface at depths of $\sim 300 \mathrm{~m}$, which also affects the DIC pool (Pedersen et al., 2012; Posiva, 2013).

The $\delta^{13} \mathrm{C}$ values of late-stage calcite fillings suggests the occurrence of a stratified geochemical environment (Fig. 4), similar to that in the present-day groundwaters. However, the mineralogical data suggests a transition to a methanogenetic environment at depths of $\sim 60 \mathrm{~m}$ with the occurrence of a possible methanotrophic zone at $\sim 34 \mathrm{~m}$. This zone is found at $\sim 300 \mathrm{~m}$ (Fig. 2) in current groundwaters. Evidence for the transition of the methanogenetic environment into sulfate reducing at the depth range of 60-300 $\mathrm{m}$ is contained only in one sample (Fig. 5c). Strong zonation of the pyrite in this sample indicates complex sulfur evolution in the fracture (Sahlstedt et al., 2013). 
513 Therefore, the transition from methanogenetic to sulfidic conditions may have fluctuated, with the

514 last change of this transition initiated by the infiltration of Littorina derived $\mathrm{SO}_{4}{ }^{2-}$-rich

515 groundwaters. Consumption of the $\mathrm{CH}_{4}$ in the fracture network at depths of 60-300 m was not recorded, possibly because the geochemical conditions did not favor calcite precipitation. Drake et al. (2015b) showed that the progression of $\mathrm{C} \mathrm{CH}_{4}-\mathrm{SO}_{4}{ }^{2-}$ interface in the bedrock, where sulfate reducing bacteria primarily use methane in BSR due to the lack of other suitable substrates, can effectively consume $\mathrm{CH}_{4}$ from the fracture groundwaters and trigger the precipitation of calcite with a methanotrophic signature. It is likely that a similar progression of a sulfate-methane interface did not occur at Olkiluoto, instead, $\mathrm{CH}_{4}$ from the 60-300 $\mathrm{m}$ depth range may have been flushed from the fracture prior to the infiltration of $\mathrm{SO}_{4}{ }^{2-}$-rich waters.

\section{Conclusions}

The $\delta^{13} \mathrm{C}$ values of calcite fillings were measured in situ by SIMS. The $\delta^{13} \mathrm{C}$ values are variable, ranging from $-53.8 \%$ o to $+31.6 \%$, indicating contributions from multiple carbon sources and different geochemical processes acting in the fracture network. The in situ carbon isotope analyses revealed variations in the $\delta^{13} \mathrm{C}$ values, especially in the late-stage fillings, which were masked in conventional bulk analyses. The study was able to construct a more detailed picture of the carbon cycling related to Group 1-2 late-stage fillings and the preceding Group 3 fillings, which both precipitated in a system with BSR. Group 3 calcite fillings had $\delta^{13} \mathrm{C}$ values ranging from $-22.1 \%$ o to $+11 \%$, with most of the values between $-16 \%$ and $-10 \%$. The $\delta^{13} \mathrm{C}$ values indicate degradation of surface derived organic matter. In contrast, the $\delta^{13} \mathrm{C}$ values of late-stage calcite of Groups 1-2 varied widely from $-53.8 \%$ o to $+31.6 \%$ and showed depth dependent variation. The variation in the $\delta^{13} \mathrm{C}$ values of the late-stage calcite indicate the following geochemical stratification: 
536 1) In the shallow depth zone at $<30 \mathrm{~m}$, the calcite had a narrow range in the $\delta^{13} \mathrm{C}$ values indicating

537 consumption of surface derived organic matter in association with BSR.

538 2) In the intermediate depth of $34-54 \mathrm{~m}$, the calcite had $\delta^{13} \mathrm{C}$ values down to $-53.8 \%$ indicating that 539 anaerobic methanotrophic $\mathrm{CH}_{4}$ consumption had occurred locally.

540 3) In the deep zone of $\sim 60-400 \mathrm{~m}$, the calcite had $\delta^{13} \mathrm{C}$ values up to $+31.6 \%$ indicating

541 methanogenetic activity.

542 The geochemical stratification indicated by late-stage minerals differs from that in the present-day

543 groundwaters by the depth distribution of the sulfate-methane interface. Limited evidence from

544 mineral proxies indicate that methanogenetic conditions were succeeded by BSR in the deep zone.

545 Based on the scarcity of calcite with a methanotrophic signature, the fracture system was likely first

546 flushed from methane down to depths of approximately $300 \mathrm{~m}$, followed by the infiltration of

547 sulfate rich waters.

549 Acknowledgements

550 This study was funded by Posiva Oy. We wish to thank Kerstin Lindén at the Nordsim laboratory

551 for sample preparation, Heejin Jeon for assisting with the analysis, and Sari Lukkari at the

552 Geological Survey of Finland for assistance with SEM imaging. We wish to thank Paula Niinikoski

553 for commenting on an earlier version of the manuscript. We wish to thank associate editor Danielle

554 Fortin and an anonymous reviewer, whose critical comments and suggestions helped to improve the

555 manuscript. The Nordsim ion microprobe facility in Stockholm is financed and operated under an

556 agreement between the research councils of Denmark, Norway and Sweden and the Geological

557 Survey of Finland, with additional support from the Knut and Alice Wallenberg Foundation. This is 558 Nordsim publication number 441. 
561

562

563

564

565

566

567

568

569

570

571

572

573

574

575

576

577

578

579

580

581

582

583

584

585

586

587

588

589

590

Alm, E., Sundblad, K. and Huhma, H. 2005. Sm-Nd isotope determinations of low-temperature fluorite-calcite-galena mineralization in the margins of the Fennoscandian Shield. SKB Rapport R05-66. Svensk Kärnbränslehantering AB, Stockholm, Sweden, 58 p.

Alperin, M.J., Reeburgh, W.S. and Whiticar, M.J. 1988. Carbon and hydrogen isotopic fractionation resulting from anaerobic methane oxidation. Global Biogeochemical Cycles, vol. 2, p. 279-288.

Antler, G., Turchyn, A.V., Herut, B., Davies, A., Rennie, V.C.F. and Sivan O. 2014. Sulfur and oxygen isotope tracing of sulfate driven anaerobic methane oxidation in estuarine sediments. Estruarine, Coastal and Self Science, vol. 142, p. 4-11.

Barnes, R.O. and Goldberg, E.D. 1976. Methane production and consumption in anoxic marine sediments, Geology, vol. 4, p. 297-300.

Benner, R., Biddanda, B., Black, B. and McCarthy, M. 1997. Abundance, size distribution, and stable cabon and nitrogen isotopic compositions of marine organic matter isolated by tangentialflow ultrafiltration. Marine Chemistry, vol. 57, p. 243-263.

Björk, S. 2008. The late Quaternary development of the Baltic Sea basin. In: The BACC Author Team (Eds.). Assesment of climate change for the Baltic Sea Basin. Springer-Verlag Berlin Heidelberg, p. 398-407.

Blyth, A., Frape, S., Blomqvist, R. and Nissinen, P. 2000. Assessing the past thermal and chemical history of fluids in crystalline rock by combining fluid inclusion and isotopic investigations of fracture calcite. Applied Geochemistry 15, p. 1417-1337.

Blyth, A.R., Frape, S.K. and Tullborg, E.-L. 2009. A review and comparison of fracture mineral investigations and their application to radioactive waste disposal. Applied Geochemistry 24, p. 821835.

Bomberg, M., Nyyssönen, M., Pitkänen, P., Lehtinen, A. and Itävaara, M. 2015. Active microbial communities inhabit sulphate methane interphase in deep bedrock fracture fluids in Olkiluoto, Finland. BioMed Research International, Acticle ID 979530.

Clark, I. and Fritz, P. 1997. Environmental isotopes in hydrogeology. CRC Press, Boca Raton, London, New York. 328 p.

Detmers, J., Brüchert, V., Habicht, K.S. and Kuever, J. 2001. Diversity of sulfur isotope fractionations by sulfate-reducing prokaryotes. Applied and Environmental Microbiology, p. 888894. 
Drake, H. and Tullborg, E.-L. 2009. Paleohydrogeological events recorded by stable isotopes, fluid inclusions and trace elements in fracture minerals in crystalline rock, Simpewarp area, SE Sweden. Applied Geochemistry, vol. 24, p. 715-732.

Drake, H., Tullborg, E.-L. and Page, L. 2009. Distinguished multiple events of fracture mineralisation related to far-field orogenic effects in Paleoproterozoic crystalline rocks, Simpevarp area, SE Sweden. Lithos 110, 37-49.

Drake, H., Tullborg, E.-L., Hogmail, K.J. and Åström, M.E. 2012. Trace metal distribution and isotope variations in low-temperature calcite and groundwater in granitoid fractures down to $1 \mathrm{~km}$ depth. Geochimica et Cosmochimica Acta, vol. 84, p. 217-238.

Drake, H., Åström, M.E., Tullborg, E.-L., Whitehouse, M. and Fallick, A.E. 2013. Variablity of sulphur isotope ratios in pyrite and dissolved sulphate in granitoid fractures down to $1 \mathrm{~km}$ depth Evidence for widespread activity of sulphur reducing bacteria. Geochimica et Cosmochimica Acta, vol. 102, p. 143-161.

Drake H., Tullborg, E.-L., Whitehouse, M., Sandberg, B., Blomfeldt, T. and Åström, M.E. 2015 a. Extreme fractionation and microscale variation of sulphur isotopes during bacterial sulphate reduction in deep groundwater systems. Geochimica et Cosmochimica Acta 161, p. 1-18.

Drake, H., Åström, M., Heim, C., Bromen, C., Åström, J., Whitehouse, M., Ivarsson, M., Siljeström, S. and Sjövall, P. 2015b. Extreme ${ }^{13} \mathrm{C}$ depletion of carbonates formed during oxidation of biogenic methane in fractured granite. Nature Communications 6:7020 doi:ncomms8020

Hallbeck, L. and Pedersen, K. 2008. Characterization of microbial processes in deep aquifers of the Fennoscandian Shield. Applied Geochemistry 23, p. 1796-1819.

Haveman, S.A., Pedersen, K. and Ruotsalainen, P. 1999. Distribution and Metabolic Diversity of Microorganisms in Deep Igneous Rock Aquifers of Finland. Geomicrobiology Journal, vol. 16 p. 277-294.

Haveman, S.A. and Pedersen, K. 2002. Distribution of culturable mircoorganisms in Fennoscandian Shield groundwater. FEMS Microbiology Ecology, vol. 39, p. 129-137.

Hinrichs K.-U. and Boetius, A. 2002. The anaerobic oxidation of methane: New insights in microbial ecology and biogeochemistry. In: Wefer, G., Billet, D., Hebbeln, D., Jørgensen, B.B., Schlüter, M. and Van Weering T. (eds). Ocean Margin Systems. Springer-Verlag, Berlin, pp. 457477.

Hutri, K. 2007. An approach to palaeoseismicity in the Olkiluoto (sea) area during the early Holocene. PhD. Thesis, STUKK-A222. Helsinki, 64 pp. + Appencides

Irwin, H., Curtis, C. and Coleman, M. 1977. Isotopic evidence for source of diagenetic carbonates formed during burial of organic-rich sediments. Nature, vol. 269, p. 209-213. 
Iwatsugi, T., Satake, H., Metcalfe, R., Yoshida, H. and Hama, K. 2002. Isotopic and morphological features of fracture calcite from granitic rocks of the Tono area, Japan: a promising palaeohydrogeological tool. Applied Geochemistry 17, p. 1241-1257.

Knittel, K. and Boetius, A. 2009. Anaerobic oxidation of methane: progress with an unknown process. Annual Reviews in Microbiology 63, p. 311-334.

Klein R., Pesonen, L.J., Salminen, J. and Mertanen, S. 2014. Paleomagnetism of Mesoproterozoic Satakunta sandstone, Western Finland. Precambrian Research, vol. 244, p.156-169.

Kohonen, J. and Rämö, O.T. 2005. Sedimentary rocks, diabases, and late cratonic evolution. In: Rämö, O.T. and Haapala, I. (Eds). Precambrian geology of Finland. Elsevier, Amsterdam, p. 563604.

Korsman, K., Koistinen, J., Kohonen, M., Wenneström, M., Ekdahl, E., Honkamo, M., Idman, H., Pekkala, Y. (Eds.), 1997. Suomen kallioperäkartta - Berggrundskarta över Finland - Bedrock map of Finland 1:1 000 000. Geological Survey of Finland, Espoo, Finland.

Kotelnikova, S. 2002. Microbial production and oxidation of methane in deep subsurface. EarthScience Reviews, vol. 58, p. 367-395.

Kärki, A. and Paulamäki, S. 2006. Petrology of Olkiluoto. Posiva Report 2006-02, Posiva Oy, Olkiluoto, $77 \mathrm{p}$.

Laaksoharju, M., Tullborg, E.-L., Wikberg, P., Wallin, B., Smellie, J. 1999. Hydrogeochemical conditions and evolution at the Äspö HRL, Sweden. Applied Geochemistry 14, p. 835-859.

Larson, S.Å. and Tullborg, E.-L. 1998. Why Baltic shield zircons yield late Paleozoic, lowerintercept ages on U-Pb concordia. Geology, vol. 26 (10), p. 919-922.

Larson, S.Å., Tullborg, E.-L., Cederbom, C. and Stiberg, J.-P. 1999. Sveconorwegian and Caledonian foreland basins in the Baltic Shiel revealed by fission-track thermochronology. Terra Nova, vol. 11 (5), p. 210-215.

Martens, C.S. and Berner, R.A. 1974. Methane production in the interstitial waters of sulfatedepleted marine sediments. Science, vol. 185, p. 1167-1169.

Megonigal, J.P., Hiens, M.E. and Visscher, P.T. 2005. Anaerobic metabolism: Linkages to trace gases and aerobic processes. In: Schlesinger, W.H. (Ed.), Biogeochemistry. Holland, H.D. and Turekian K.K. (Eds.) Treatise on Geochemistry vol. 8, Elsevier-Pergamin, Oxford, p. 317-424.

Miettinen, A., Rinne, K., Haila, H., Hyvärinen, H., Eronen, M., Delusina, I., Kadastik, E., Kalm, V. and Gibbard, P. 2002. The marine Eemian of the Baltic: new pollen and diatom data from Peski, Russia, and Põhja-Uhtju, Estonia. Journal of Quaternary Science, vol. 17(5-6) p. 445-458.

Nyyssönen, M., Bomberg, M., Kapanen, A., Nousiainen, A., Pitkänen, P. and Itävaara, M. 2012. Methanogenic and sulphate-reducing microbial communities in deep groundwater of crystalline rock fractures in Olkiluoto, Finland. Geomicrobiology Journal 29, p. 863-878. 

of ancient life at $207 \mathrm{~m}$ depth in a granitic aquifer. Geology 25, p. 827-830.

Pedersen, K., Arlinger, J., Eriksson, S., Hallbeck, A., Hallbeck, L. and Johansson J. 2008. Numbers, biomass and cultivable diversity of microbial populations relate to depth and borehole-spacific conditions in groundwater from depths of $4-450 \mathrm{~m}$ in Olkiluoto, Finland. The ISME Journal 2, p. 760-775.

Pedersen, K., 2013. Metabolic activity of subterranean microbial communities in deep granitic groundwater supplemented with methane and $\mathrm{H}_{2}$. The ISME Journal, p. 1-11.

Pedersen, K., Bomberg, M. and Itävaara, M. 2014. Summary report, microbiology of Olkiluoto and ONKALO groundwater. Posiva Report 2012-42, Posiva Oy, Olkiluoto, 102 p.

Pitkänen, P., Partamies, S. and Luukkonen A. 2004. Hydrogeochemical Interpretation of Baseline Groundwater Conditions at the Olkiluoto Site. Posiva Report 2003-07, Posiva Oy, Olkiluoto. 159 p. Posiva, 2011. Olkiluoto Site Description 2011. Posiva Oy Olkiluoto, 1028 p.

Posiva 2013. Olkiluoto Site Description 2011, Posiva Report 2011-02, Posiva Oy, Olkiluoto, 1101 p.

Poore, H.R., Samworth, R., White, N.J., Jones, S.M. and McCave, I.N. 2006. Neogene overflow of northern component water at the Greenland-Scotland Ridge. Geochemistry Geophysics Geosystems, vol. 7 (6), 24 p.

Reeburgh, W.S. 1976. Methane consumption in Cariaco Trench waters and sediments. Environmental Science Technology, vol. 2, p. 140-141.

Roedder, E. 1984. Reviews in Mineralogy vol. 12, Fluid inclusions. Mineralogical Society of America, Washington D.C.

Sahlstedt, E., Karhu, J.A. and Pitkänen, P. 2010. Indications for the past redox environments in deep groundwaters from the isotopic composition of carbon and oxygen in fracture calcite, Olkiluoto, SW Finland. Isotopes in Environmental and Health Studies, vol. 46 (3), p. 370-391.

Sahlstedt, E., Karhu, J., Pitkänen, P. and Whitehouse, M. 2013. Implications of sulfur isotope fractionation in fracture-filling sulfides in crystalline bedrock, Olkiluoto, Finland. Applied Geochemistry, vol. 32, p. 52-69.

Sandström, B. and Tullborg, E.-L., 2009. Episodic fluid migration in the Fennoscandian Shield recorded by stable isotopes, rare earth elements and fluid inclusions in fracture minerals at Forsmark, Sweden. Chemical Geology 266, 126-142.

Sandström, B., Tullborg, E.-L., Larson, S.Å. and Page, L. 2009. Brittle tectonothermal evolution in the Forsmark area, central Fennoscandian Shield, recorded by paragenesis, orientation and 40Ar/39Ar geochronology of fracture minerals. Tectonophysics, vol 478, p. 158-174. 
Sim, M.S., Bosak, T. and Ono, S. 2011. Large sulfur isotope fractionation does not require disproportionation. Science, vol. 333, p. 74-77.

Stotler, R.L., Frape, S.K., Ruskeeniemi, T., Pitkänen, P. and Blowes, D.W. 2012. The interglacialglacial cycle and geochemical evolution of Canadian and Fennoscandian Shield groundwaters. Geochimica et Cosmochimica Acta 76, p. 45-67.

Tullborg, E.-L., Larson, S.Å., Björklund, L., Samuelsson, L. and Sigh, J. 1995. Thermal evidence of Caledonian foreland molasse sedimentation in Fennoscandia. Swedish Nuclear Fuel and Waste Management Co (SKB), Technical Report 95-18.

Vaasjoki, M. 1996. The Laitila rapakivi batholith revisited: new, more precise radiometric ages. In: Haapala, I., Rämö, O.T. and Kosunen, P. (eds) The seventh International Symposium on Rapakivi Granites and Related Rocks, Wednesday 24- Friday 26 July, 1996, University of Helsinki, Helsinki - Finland: abstrackt volume. Helsinki: University Press, p. 82.

Veizer, J., Ala, D., Azmy, K., Bruckschen, P., Buhl, D., Bruhn, F., Carden, G.A.F. Diener, A., Ebneth, S., Gobberis, Y., Jasper, T., Korte, C., Pawellek, F., Podlaha, O.G. and Strauss, H. 1999. ${ }^{87} \mathrm{Sr} /{ }^{86} \mathrm{Sr}, \delta^{13} \mathrm{C}$ and $\delta^{18} \mathrm{O}$ evolution of Phanerozoic seawater. Chemical Geology, vol. 161, p. 59-88.

Widerlund, A. and Andersson, P.S. 2011. Late Holocene freshening of the Baltic Sea derived from high-resolution strontium isotope analyses of mollusk shells. Geology, vol. 39 (2), p. 187-190.

Winterhalter, B. 1972. On the geology of the Bothnian Sea, an epeiric sea that has undergone Pleistocene glaciation. Geological Survey of Finland, Bulletin 258, p. 1-66.

Whiticar, M.J. 1999. Carbon and hydrogen isotope systematics of bacterial formation and oxidation of methane. Chemical Geology, vol. 161, p. 291-314.

Whiticar, M.J. and Faber, E. 1986. Methane oxidation in sediment and water column environments - isotope evidence. Organic Chemistry 10, p. 756-768.

Whiticar, M.J., Faber, E. and Schoell, M. 1986. Biogenic Methane Formation in Marine and Freshwater Environments: CO2 Reduction vs. Acetate Fermentation - Isotope Evidence, Geochimica et Cosmochimica Acta vol. 50, p. 693-709.

Wortmann, U.G., Bernasconi, S.M and Böttcher, M.E. 2001. Hypersulfidic deep biosphere indicates extreme sulfur isotope fractionation during single-step microbial sulfate reduction. Geology 29, p. 647-650. 
Figure captions:

725

726

727

728

729

730

731

732

733

734

735

736

737

738

739

740

741

742

743

744

745

746

Figure 1. Geological setting. a) Geology of the Olkiluoto region. (1) Svecofennian supracrustal and synorogenic plutonic rocks, (2) Svecofennian late orogenic granites, (3) sandstone, (4) rapakivi granite, (5) gabbro, (6)-(8) diabase dykes (modified after Korsman et al., 1997). b) Lithological map of the Olkiluoto island. The map shows the location of the drill core used in the study, with the exception of cores ONK-PH2 and ONK-PH11 which were drilled along the construction tunnels for the repository (ONKALO) (modified from Posiva, 2011).

Figure 2. Schematic illustration of the hydrogeochemical characteristics at Olkiluoto. a)

Geochemical stratification of the groundwaters. In the fracture networks infiltration proceeds deeper than in less fractured bedrock. Otherwise the groundwater compositions are roughly horizontally stratified (modified after Pitkänen et al., 2004). b) The $\delta^{13} \mathrm{C}$ values of groundwaters with respect to depth, divided into the respective hydrogeochemical water types. The $\delta^{13} \mathrm{C}$ values are typically <$10 \%$, except for few analyses from the shallow bedrock and few from the brackish $\mathrm{Cl}^{-}$-type groundwaters. Also shown in the figure are the DIC and DOC (dissolved organic carbon) concentrations, in $\mathrm{mg}$ of carbon per liter of water $(\mathrm{mgC} / \mathrm{L})$. High DOC concentrations in deep groundwaters $(>200 \mathrm{~m}$ ) reflect the contribution from hydrocarbon gases and contamination from the sampling hoses (after Posiva, 2013).

Figure 3. Histograms showing the distributions of $\delta^{13} \mathrm{C}$ values in Group 3 and Group 1-2 calcite fillings. The figure shows that the variation in the $\delta^{13} \mathrm{C}$ values is larger in Group 1-2 fillings compared to Group 3 fillings. The $\delta^{13} \mathrm{C}$ values of both Group 3 and Group 1-2 fillings show a peak at $-18 \%$ to $-12 \%$, but the peak for Group 3 fillings is more pronounced. 
748 Figure 4. The $\delta^{13} \mathrm{C}$ values of the calcite fillings with respect to depth. The C-isotopic compositions 749 measured by SIMS are divided between Groups 3 and 1-2. Note the depth dependent trend in the

$750 \quad \delta^{13} \mathrm{C}$ values of Group 1-2 calcite, which change from strongly negative to strongly positive at depths 751 of $\sim 50-60 \mathrm{~m}$. In comparison, similar trends are not apparent in the $\delta^{13} \mathrm{C}$ values of Group 3 calcite.

752 Also, the $\delta^{13} \mathrm{C}$ values of groundwater DIC (striped area) do not show any clear depth dependent 753 trends. The $\delta^{13} \mathrm{C}$ values of DIC are according to Posiva (2013).

Figure 5. Back scattered electron images of calcite fillings and the variation in the $\delta^{13} \mathrm{C}$ values. The $\delta^{13} \mathrm{C}$ values for the analysis spots are given in \%o. a) Sample OL-KR19/42.19-42.25 represents Group 1 calcite. The $\delta^{13} \mathrm{C}$ values are highly variable within the precipitate, with the lowest values found at the edge of the crystals. b) Two pieces of sample OL-KR53/65.74-65.81 filling (Group 1). The $\delta^{13} \mathrm{C}$ values are highly variable within distances of $<100 \mu \mathrm{m}$. c) Sample OL-KR38/102.46102.67 (Group 3 at the bottom and Group 1 at the surface). Positive $\delta^{13} \mathrm{C}$ values are found at the

761 very surface of the filling. Calcite precipitation was followed by pyrite precipitation, as seen in the secondary electron images showing a close up of the surface of the fillings. d) Sample OLKR24/112.64-112.69 (Group 3 at the bottom and Group 2 at the surface). The very surface of the fillings contains calcite with highly positive $\delta^{13} \mathrm{C}$ values. The dark bands seen on the top layers of calcite are caused by silicate inclusions in the calcite.

Figure 6 . The $\delta^{13} \mathrm{C}$ values of calcite and $\delta^{34} \mathrm{~S}$ on pyrite with respect to sample depth. In the upper diagrams are shown the $\delta^{13} \mathrm{C}$ and $\delta^{34} \mathrm{~S}$ values of Group 3 fillings and in the lower diagrams the $\delta^{13} \mathrm{C}$ and $\delta^{34} S$ values of Group 1-2 fillings. Sulfur isotope data is from Sahlstedt et al. (2013), and the bulk carbon isotope data from Sahlstedt et al. $(2010 ; 2013)$ and Table S3. a) The $\delta^{13} \mathrm{C}$ values of 
771 Group 3 calcite (SIMS analyzes in filled boxes, bulk values in filled circles) do not show trends

772 with respect to depth. The $\delta^{34} S$ values of Group 3 pyrite show a large variation through the sampled

773 depth range. b) The $\delta^{13} \mathrm{C}$ values of Group 1-2 calcite show depth dependent variation, which is

774 more clearly seen in the SIMS results (dark grey) than in the bulk results (light grey). The $\delta^{13} \mathrm{C}$

775 values vary in a narrow range at depths $<30 \mathrm{~m}$ and change from negative to positive at depths of $776 \sim 50-60 \mathrm{~m}$. 

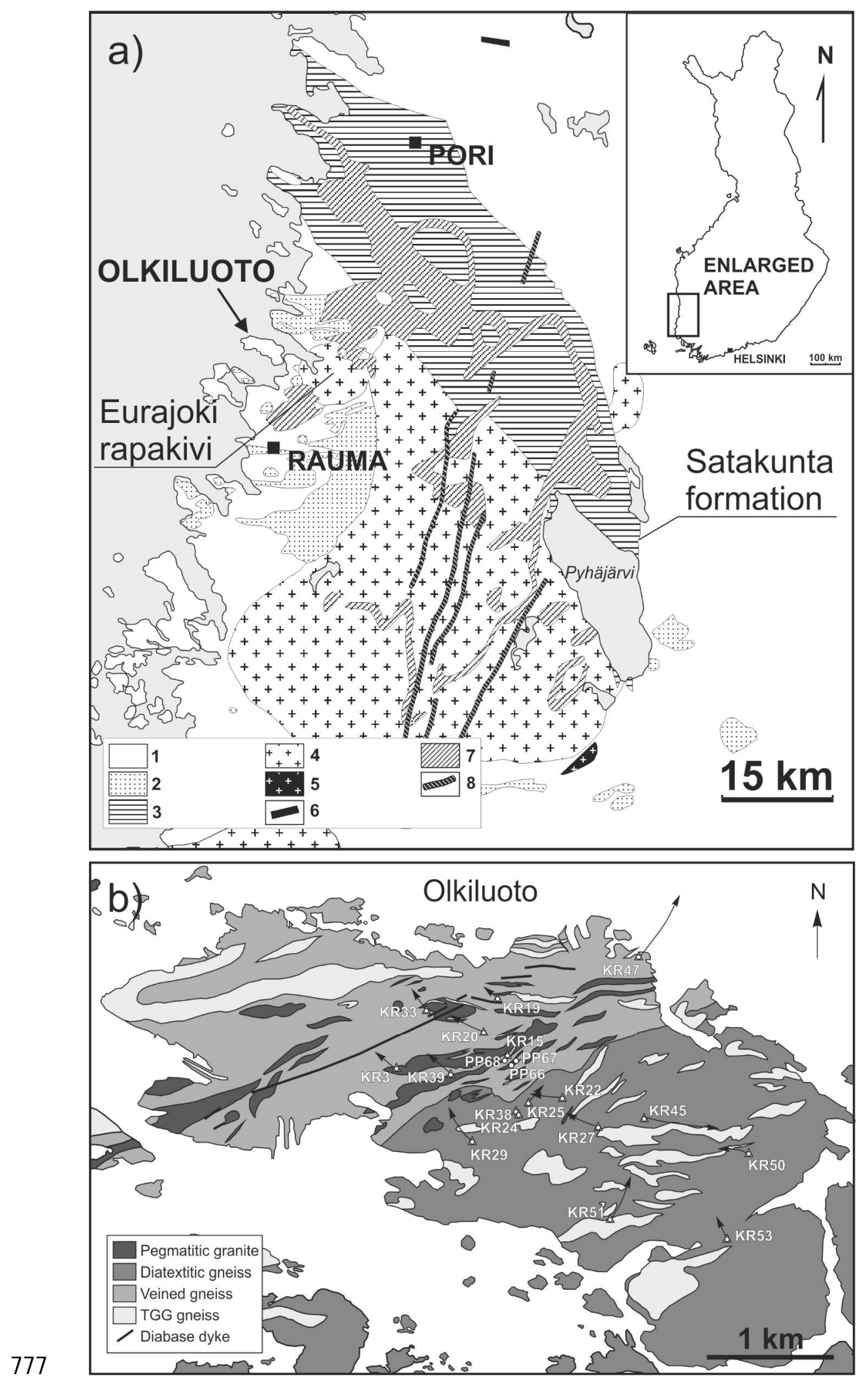

778 Figure 1. 
a)

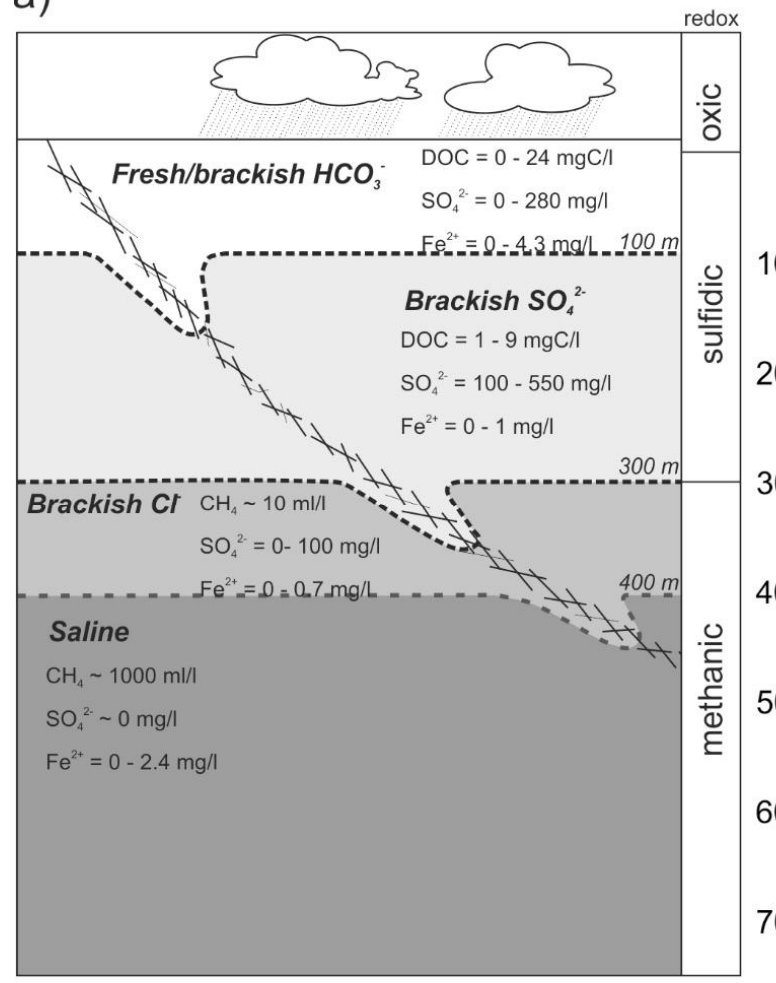

780

\section{Figure 2.}

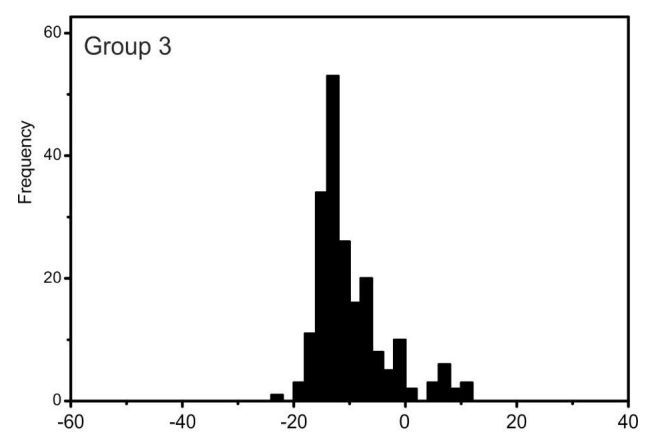

782

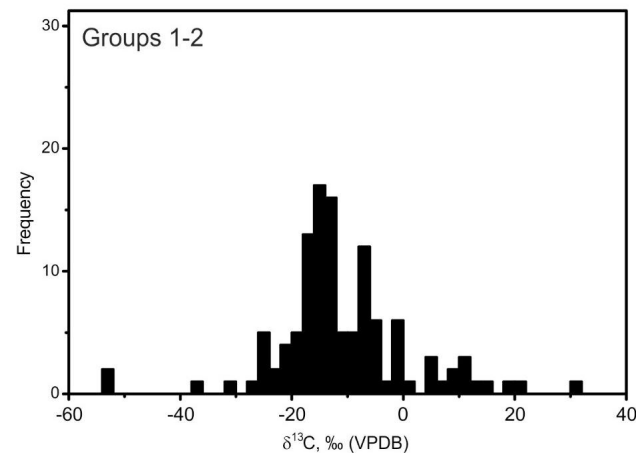

b)

DIC, DOC (mgC/L)

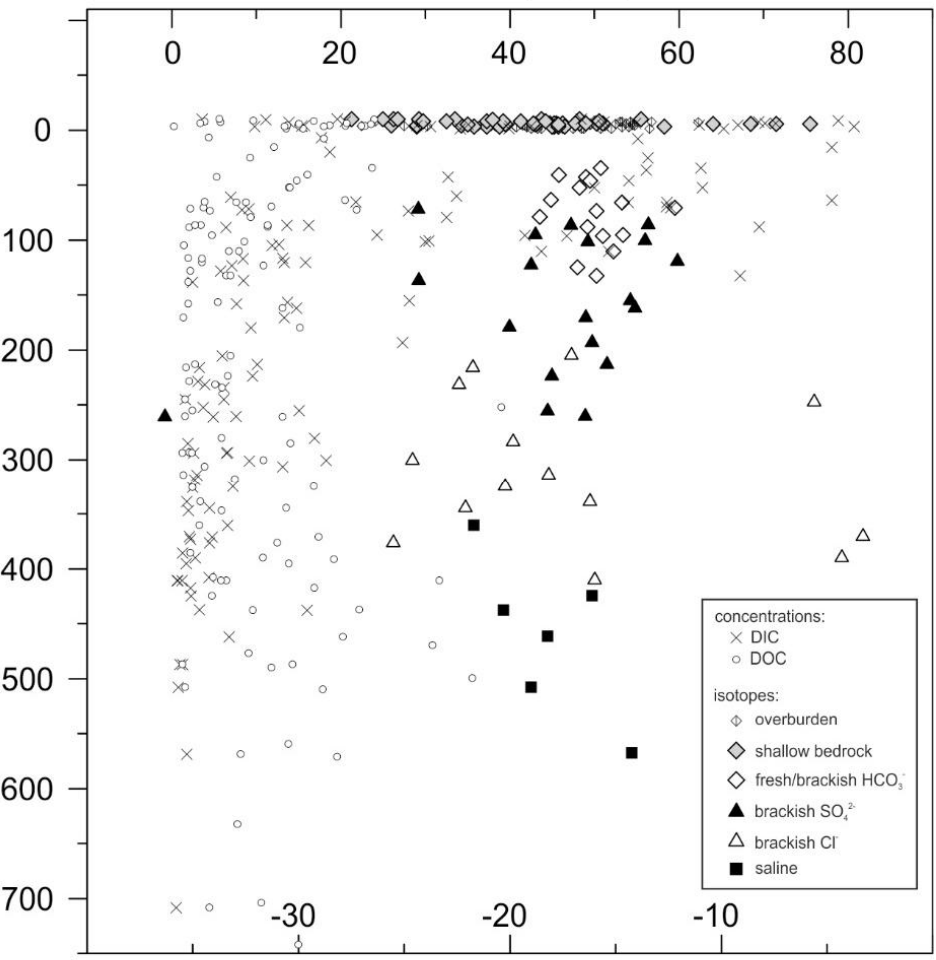

$\delta^{13} \mathrm{C}(\%$, VPDB $)$ 


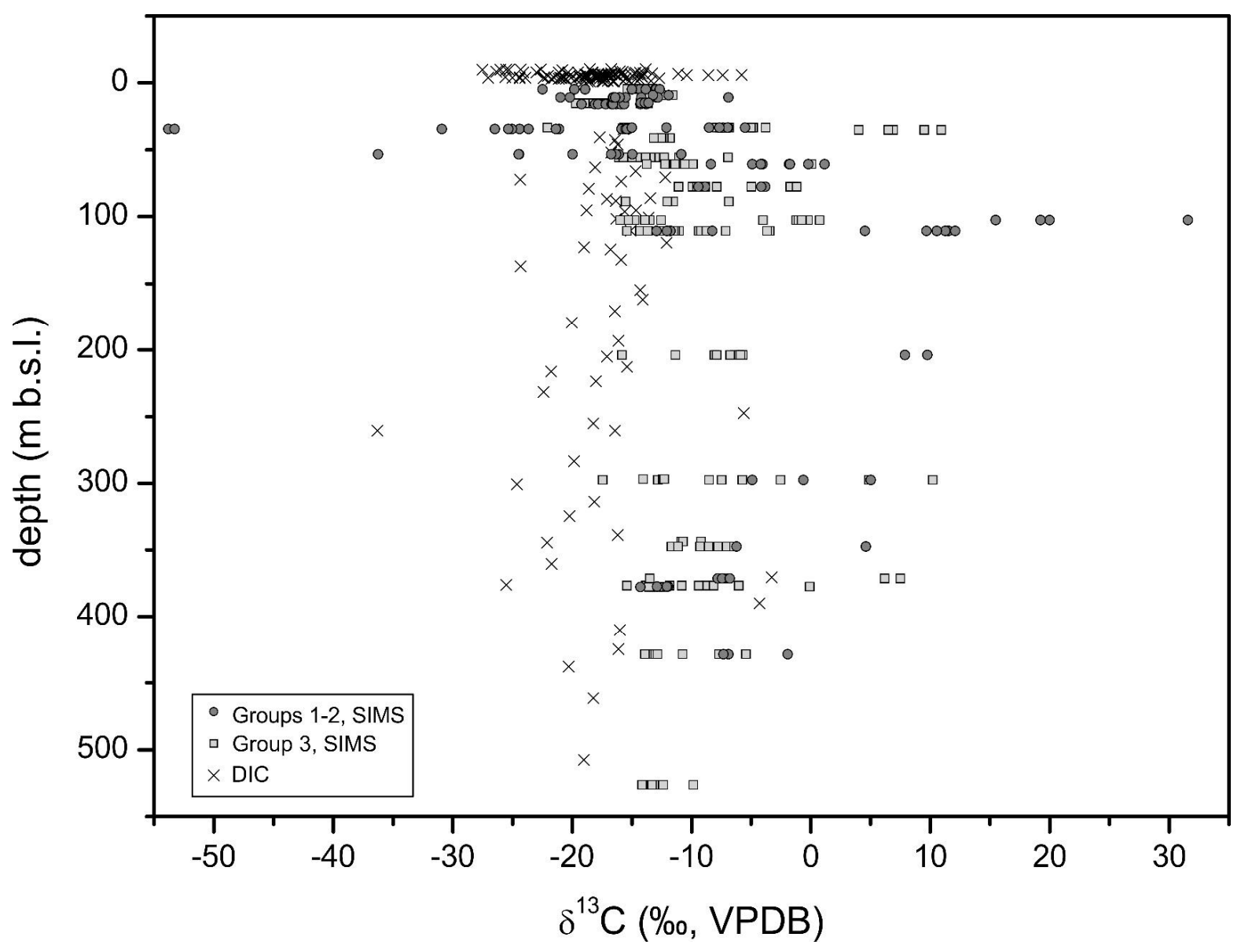

785 Figure 4. 


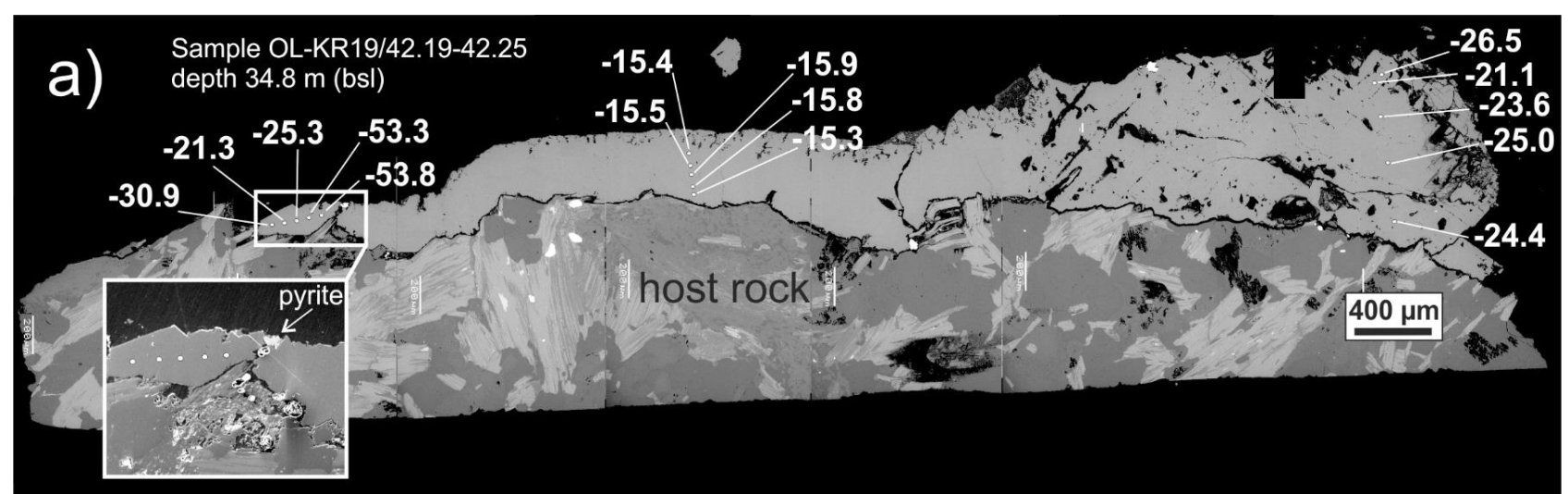

Sample OL-KR53/65.74-65.81, depth 53.7 m (bsl)

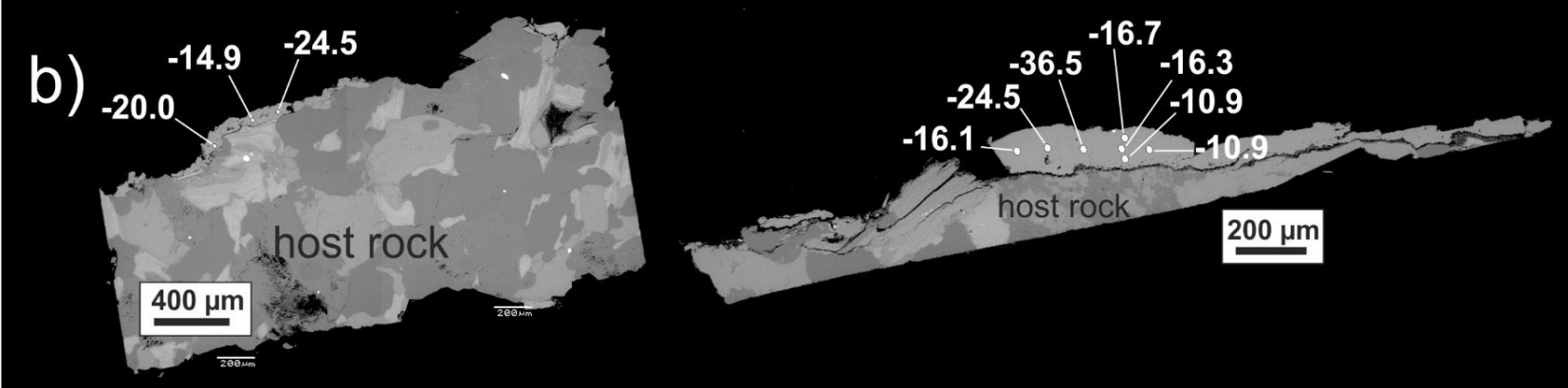

Sample OL-KR38/102.46-102.67, depth 111 m (bsl)

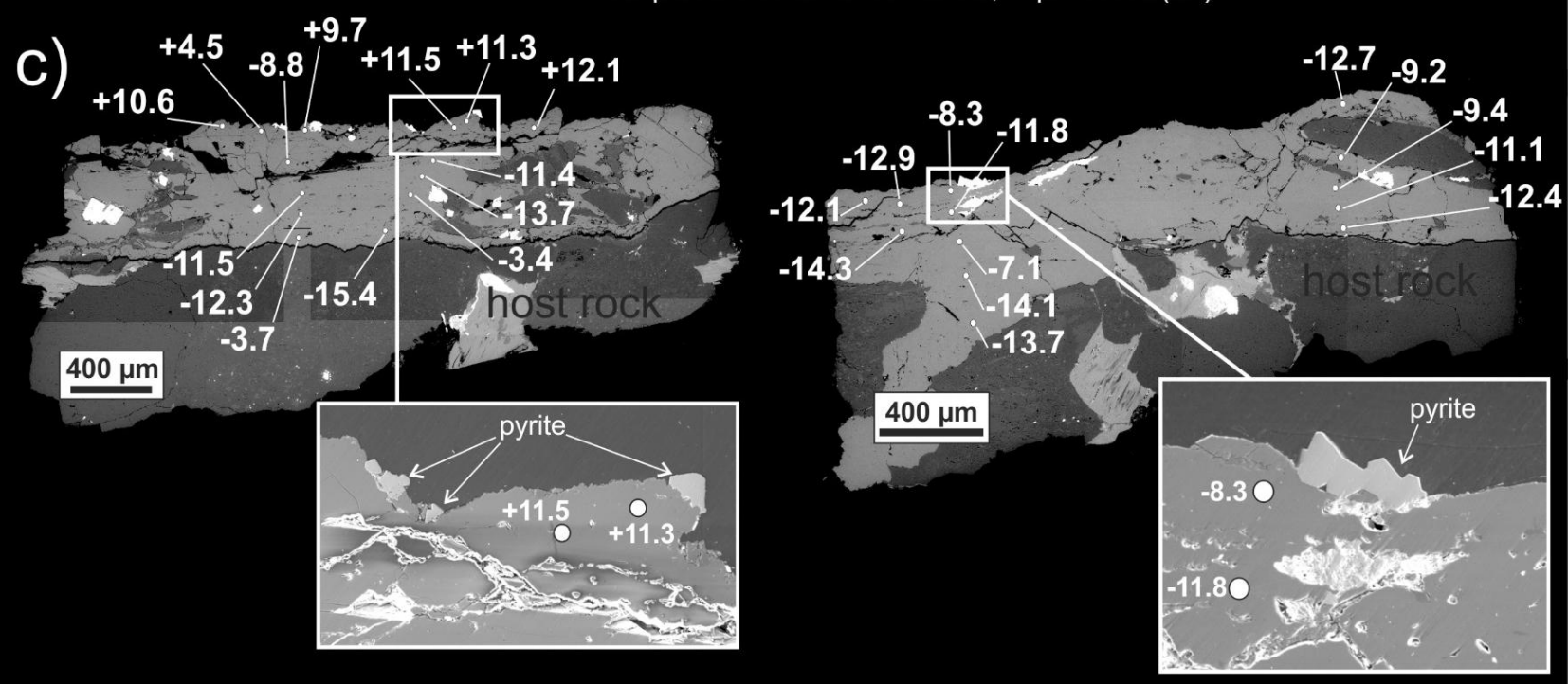

d)

Sample OL-KR24/112.64-112.69, depth 102.9 m (bsl)

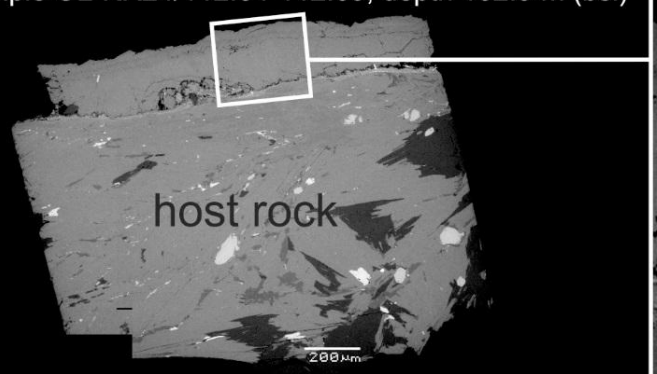

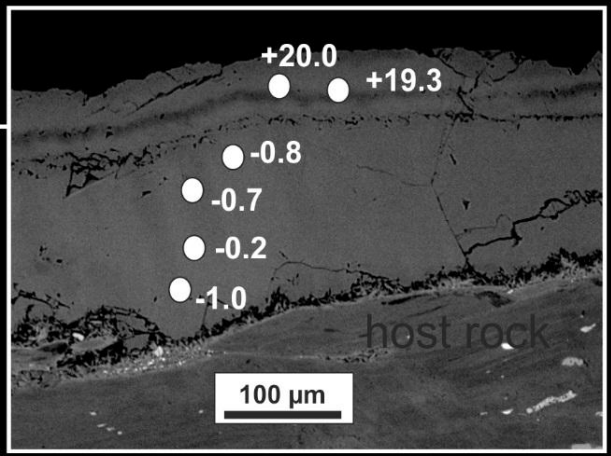


Figure 5.
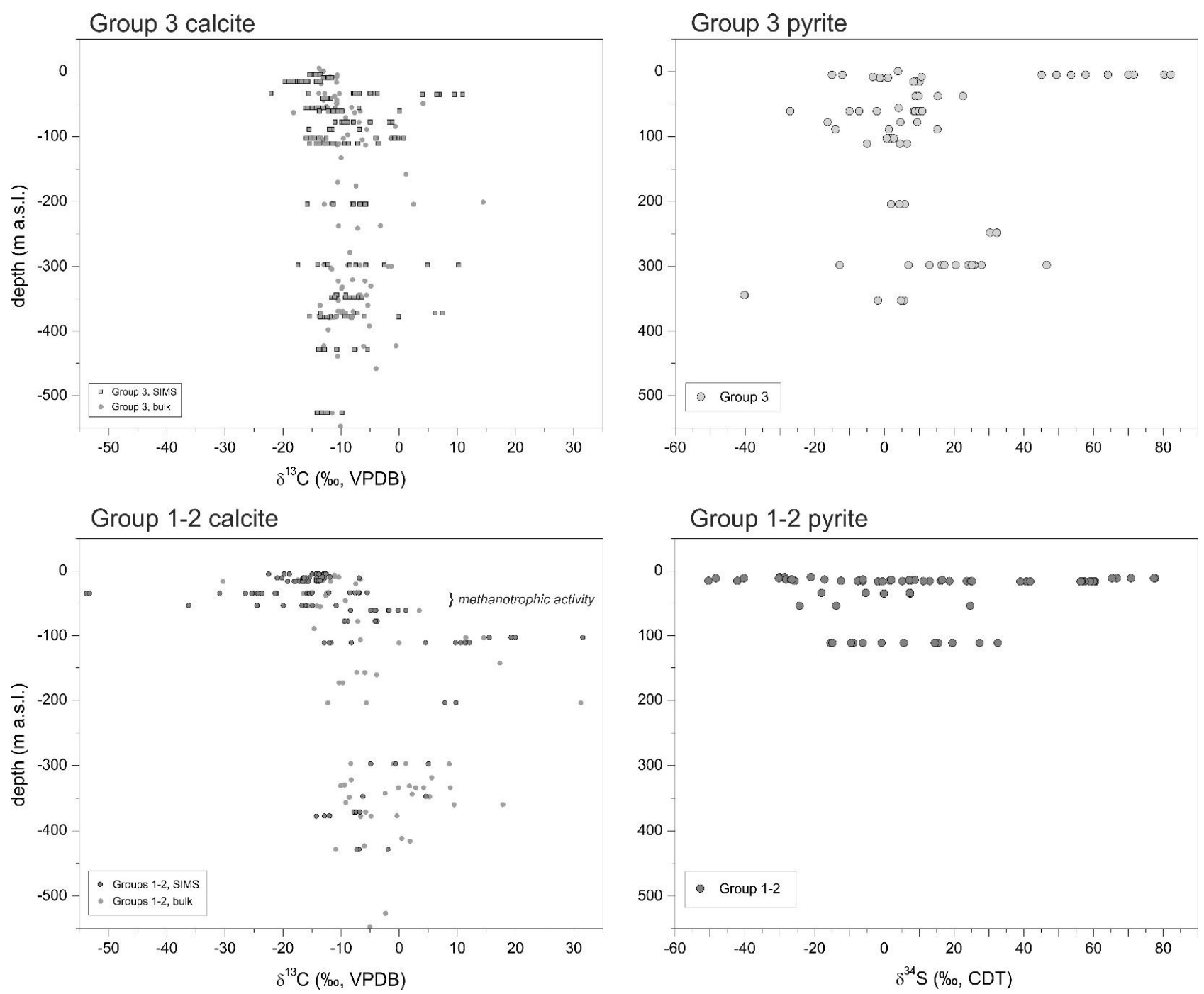

789 Figure 6. 